\title{
Common Variable Immunodeficiency: Epidemiology, Pathogenesis, Clinical Manifestations, Diagnosis, Classification, and Management
}

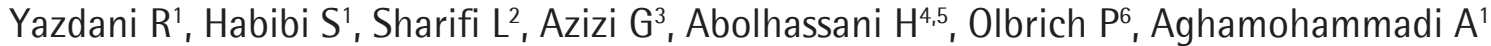 \\ 'Research Center for Immunodeficiencies, Pediatrics Center of Excellence, Children's Medical Center, Tehran University of Medical Science, \\ Tehran, Iran. \\ ${ }^{2}$ Uro-Oncology Research Center, Tehran University of Medical Sciences, Tehran, Iran \\ ${ }^{3}$ Non-Communicable Diseases Research Center, Alborz University of Medical Sciences, Karaj, Iran. \\ ${ }^{4}$ Research Center for Primary Immunodeficiencies, Iran University of Medical Science, Tehran, Iran. \\ ${ }^{5}$ Division of Clinical Immunology, Department of Laboratory Medicine, Karolinska Institute at Karolinska University Hospital Huddinge, \\ Stockholm, Sweden. \\ ${ }^{6}$ Sección de Infectología e Inmunopatología, Unidad de Pediatría, Hospital Virgen del Rocio/Instituto de Biomedicina de Sevilla (IBiS), Seville, \\ Spain
}

J Investig Allergol Clin Immunol 2020; Vol. 30(1): 14-34

doi: 10.18176/jiaci.0388

\section{Abstract}

Common variable immunodeficiency (CVID) is a heterogeneous disorder characterized by hypogammaglobulinemia and increased susceptibility to recurrent bacterial infections. It is the most frequent symptomatic antibody deficiency, with a wide variety of infectious and noninfectious complications. Numerous studies have demonstrated that immunological and genetic defects are involved in the pathogenesis of CVID. However, in most cases, the genetic background of the disease remains unidentified. This review aims to discuss various aspects of CVID, including epidemiology, pathogenesis, symptoms, diagnosis, classification, and management.

Key words: Common variable immunodeficiency. Epidemiology. Pathogenesis. Symptoms. Diagnosis. Classifications. Management.

\section{Resumen}

La inmunodeficiencia variable común (CVID) es un trastorno heterogéneo caracterizado por una hipogammaglobulinemia y por una mayor susceptibilidad a infecciones bacterianas recurrentes. Se trata de la inmunodeficiencia humoral sintomática más frecuente y cursa con una extensa variedad de complicaciones infecciosas y no infecciosas. En la patogenia de la CVID están involucrados diferentes defectos inmunológicos y genéticos. Sin embargo, en la mayoría de los casos, el fondo genético de la enfermedad permanece sin identificar. Esta revisión tiene como objetivo discutir diferentes aspectos de la CVID, incluyendo epidemiología, patogenia, síntomas, diagnóstico, clasificaciones y tratamiento de la enfermedad.

Palabras clave: Inmunodeficiencia variable común. Epidemiología. Patogenia. Síntomas. Diagnóstico. Clasificaciones. Tratamiento. 


\section{Introduction}

Common variable immunodeficiency (CVID) is the most common symptomatic primary immunodeficiency (PID). It is characterized by hypogammaglobulinemia and impaired production of specific immunoglobulin (Ig). Patients with CVID present a broad range of clinical manifestations, including recurrent bacterial infections, autoimmunity, interstitial lung disease, enteropathy, lymphoproliferation, malignancy, and allergic diseases [1,2]. In recent years, several monogenic disorders involved in the presentation of CVID have been identified; however, these affect less than $20 \%$ of CVID patients in nonconsanguineous cohorts [3] and approximately $70 \%$ of CVID patients in consanguineous cohorts [4]. Furthermore, several abnormalities in the innate and adaptive immune systems have been reported [5-7], although the exact molecular defects leading to CVID remain unknown.

Classifications have been defined for CVID patients based on various clinical manifestations and immunological data [8]. Since CVID is considered a heterogeneous group of PIDs with various clinical and immunological features, appropriate classification of affected patients is essential. Regarding the diagnosis of CVID, describing the clinical features and immunological and genetic analysis are the most important steps. Clinical heterogeneity in CVID patients has led to diagnostic challenges and difficulties in determining the optimal treatment [9]. Although immunoglobulin replacement therapy is the mainstay of the treatment for CVID patients, hematopoietic stem cell transplantation (HSCT) is used for CVID patients with cellular immune defects and therapy-resistant autoimmunity. This potentially curative treatment approach has been applied in some cases of CVID, with mixed results. Few data are available on the advantages of new immunomodulation techniques applied via targeted treatment in a selected group of CVID patients with specific genetic defects [10].

The aim of this review is to present a comprehensive view of CVID covering epidemiology, pathogenesis, clinical manifestations, diagnosis, and classification.

\section{Epidemiology}

Antibody deficiencies are the most common defect among PIDs and affect $30 \%-70 \%$ of all patients identified with a specific defect. Within the PID group, CVID is the most frequent symptomatic antibody deficiency [11]. According to a recent report by the Jeffrey Modell Centers Network, there are important geographic disparities in the prevalence of CVID, as follows: North America $(n=6443)$, Europe $(n=4279)$, Asia $(n=459)$, Australia $(n=657)$, and Africa $(n=156)$ [12]. The highest prevalence of CVID has been documented in the USA ( $40.2 \%$ of all PID patients), whilst the lowest rates were observed in the Middle East (2.6\%) and Africa (1.3\%) [12]. The most likely reasons for these differences are the availability of appropriate diagnostic methods and registry data and awareness of PID [13].

In CVID, the age of onset is associated with the predominant clinical manifestations. The United States Immunodeficiency Network (USIDNET) database compared pediatric patients
( $\leq 17$ years) with adult patients $(\geq 18$ years) ( $n=457$ patients) and found that otitis media, developmental delay, and failure to thrive were more frequent in pediatric-onset CVID patients, whilst bronchitis, arthritis, and fatigue were more common in adult CVID patients [14].

\section{Pathogenesis}

Various studies have investigated the pathogenesis of CVID. Identification of the causes of monogenetic CVID has increased our understanding of this complex disease $[9,15]$. In addition, recent studies demonstrated the role of epigenetic modifications in the development of disorders associated with CVID $[16,17]$. Gene mutations at 3 cellular levels (surface, cytoplasm, and nucleus) are shown in Tables 1, 2, and 3, respectively.

\section{Genetic and Molecular Defects}

Different members of the tumor necrosis factor (TNF) receptor superfamily have been reported to be involved in the pathogenesis of CVID. The single gene defects reported in this pathway affect transmembrane activator and calcium modulator and cyclophilin ligand interactor (TACI, encoded by $T N F R S F 13 B$ ), B-cell activating factor belonging to the tumor necrosis factor family BAFF receptor (BAFF-R, encoded by TNFRSF 13C), TNF-like weak inducer of apoptosis (TWEAK, encoded by TNFRSF12), and CD27 encoded by TNFRSF7. BAFF-R and TACI are known to participate in $\mathrm{B}$-cell development and activation by engaging a proliferationinducing ligand (APRIL) and/or BAFF $[18,19]$. Although studies have demonstrated that $8 \%-10 \%$ of CVID patients have a defect in TACI, these mutations have also been described in the general population without hypogammaglobulinemia, thus raising the question of their pathologic impact. Since TACI regulates the function of the $\mathrm{B}$-cell receptor $(\mathrm{BCR})$ and the Tolllike receptor (TLR) 7 and 9 molecules, defects in molecules could result in impairment of B-cell activation/maturation, which may then lead to autoimmune manifestations $[18,20]$. In addition to the TNF receptor superfamily, defects in the CD19 complex (CD19, CD21, and CD81) or costimulatory molecules, such as the CD20 and IL-21 receptors, have also been described in CVID patients. These molecules are important for appropriate development, maturation, and survival of B cells and are likely involved in the pathogenesis of CVID [5]. Furthermore, defects in 2 costimulatory and inhibitory receptors located on $\mathrm{T}$ cells (inducible costimulator [ICOS] and cytotoxic T-lymphocyte associated protein 4 [CTLA-4]) were identified in a group of CVID-like patients with associated T-cell abnormalities [5].

In recent years, defects in several signaling-associated molecules implicated in the pathogenesis of CVID have been identified at the level of the surface, cytoplasm, and nucleus. The detailed functions and effects of the most important defects are summarized in Tables 1, 2, and 3. Nowadays, each defective molecule is considered a separate form of immunodeficiency and is categorized as a monogenic disorder. In this sense, The International Union of Immunological Societies (IUIS) has classified PID disorders into specific categories [21]. 


\section{Epigenetic Changes}

Several recent studies have highlighted the role of epigenetic factors in the pathogenesis of CVID [16,17,22,23]. Epigenetic mechanisms can influence gene expression without altering the germline DNA gene sequences and play an important role in the normal developmental program of immune cells [16]. The mechanisms described to date include DNA methylation, chromatin modulation, histone modification, transcription factor expression, and noncoding RNAs (ncRNAs) [24].

DNA methylation is catalyzed by DNA methyltransferases and represses gene expression by reducing transcription factors and DNA regulatory elements or by making DNA fragments inaccessible to transcription factors [25]. This mechanism plays an important role in both early and late stages of B-cell development. A study of twins who were discordant for a diagnosis of CVID revealed a higher degree

Table 1. Surface Molecular Defects in Patients With Common Variable Immunodeficiency

\begin{tabular}{lll}
\hline Gene & Function & Ref \\
\hline TACI (encoded & Function: Regulation of BCR, TLR7, and TLR9 function & [18,20, \\
by TNFRSF13B) & Effect of deficiency: B-cell activation defect and autoimmune manifestation & $162]$ \\
BAFF-R (encoded & Function: Regulation of B-cell survival and maturation & [43] \\
by TNFRSF13C) & $\begin{array}{l}\text { Effect of deficiency: Low peripheral B-cell numbers, increased transitional B cells, decreased } \\
\text { antibody responses to polysaccharide vaccine }\end{array}$ & \\
TWEAK (encoded & Function: Promotion of endothelial cell proliferation and polarization of immune system
\end{tabular}

by TNFRSF12)

CD27 (encoded by TNFRSF7)

CD19 complex (CD19, CD81 and $C D 21)$

IL21R and its ligand (IL21)

ICOS

CD20 (MS4A1)

FC $\mathrm{R}$ IIa

CTLA-4 to $\mathrm{T}_{\mathrm{H}} 1$ adaptive responses

Effect of deficiency: Inhibition of B-cell survival and proliferation, inhibition of Ig class switching by downregulation of the noncanonical BAFF-induced NF- $\kappa B$ pathway

Function: Participation in T, B, and NK-cell function

Effect of deficiency: Hypogammaglobulinemia, abnormal T cell-dependent B-cell response, disturbed T-cell function, absent memory B cells

Function: Attenuation of B-cell activation threshold and thus signaling enhancement as a result of cobinding of this complex by B-cell receptor

Effect of deficiency: Impaired BCR/coreceptor complex signaling, defective somatic hypermutation and CSR, reduced memory B cells and plasma cells are seen in both CD19- and CD81-deficient patients

Hypogammaglobulinemia, reduced number of memory B cells, and increased naïve mature $\mathrm{B}$ cells have been observed in CD21-deficient patients

Function: IL21-IL21R interaction is required for germinal center formation, proliferation and class switch recombination of B cells, plasma cell differentiation, and eventually immunoglobulin production

Effect of deficiency: defects in class switch recombination, variable dysfunctions of NK-cell cytotoxicity, decreased T-cell proliferation, reduced numbers of circulating, marginal zone-like and class-switched memory B cells, increased number of transitional cells, increased IgE levels and reduced IgG levels

Function: Regulation of terminal B-cell differentiation in germinal centers, T-cell tolerance, and also effector T-cell responses

Effect of deficiency: Severe reduction in B-lymphocyte counts, low levels of serum concentrations of $\operatorname{IgM}$ and switched Ig isotype, lack of the expression of maturation and memory marker CD27 on B cells

Function: Regulation of $\mathrm{Ca}_{2}{ }^{+}$transport across the plasma membrane

Effect of deficiency: Severe reduction in switched memory B cells, decreased IgG level with relatively increased $\operatorname{IgM}$ and weak responses against polysaccharides after vaccination, reduction in the frequency of somatic hypermutation in IgG heavy chain

Function: Recognition of FC region of IgG

Effect of deficiency: Increased sensitivity of neutrophils to immune complexes, anaphylactoid reactions to immunoglobulin infusions, suppressed signaling cascade in B cells due to MAPK phosphorylation

$[166-170]$

Function: Suppression of immune responses by negative signaling and therefore preventing excessive T-cell activation

Effect of deficiency: Impaired function of Treg cells, reduced circulating B cells, increased autoreactive $\mathrm{CD} 21^{\text {low }}$

Abbreviations: BCR, B-cell receptor; TLR, Toll-like receptors; BAFF, B-cell activating factor; $\mathrm{T}_{\mathrm{H}}$ T helper cells; CSR, class switch recombination; NF- $\mathrm{KB}$, nuclear factor $\kappa$-light-chain-enhancer of activated $B$ cells. 
Table 2. Cytosolic Defects in Patients With Common Variable Immunodeficiency

Gene Function Ref

$P K C \delta \quad$ Function: Involved in BCR-mediated signaling and participates in the regulation of cellular processes

$[181-183]$ including proliferation, differentiation, apoptosis, and tolerance Effect of deficiency: Decrease in CD19 B cells, low numbers of memory B cells, as well as increased numbers of CD2 $1^{\text {low }} \mathrm{B}$ cells

$P L C \gamma 2 \quad$ Function: Participation in B-cell receptor signaling Effect of deficiency: Defective calcium flux and phosphorylation of ERK in response to IgM cross-linking, abnormal class switch recombination and receptor editing, and antibody deficiency

PI3K Function: B- and T-cell homoeostasis

(PI3KR1, Effect of deficiency: Expanded CD8 T cells, agammaglobulinemia, increased frequency of transitional

$P I 3 L C D) \quad B$ cells, decreased numbers of naive CD4 and CD8 T cells, and increased numbers of CD8 effector/memory $\mathrm{T}$ cells, normal or often increased serum IgM levels, cell death induced by increased T-cell activation

BLK Function: Member of the Src kinase family, which is involved in BCR signaling Effect of deficiency: Diminished B-cell proliferation and T-cell help, with subsequently reduced numbers of class-switched memory B cells and defective production of high affinity antibody

IP3 Function: Induction of mobilization of calcium to the cytosol, resulting in elevation of the intracellular $\mathrm{Ca}^{+}$that is necessary for induction of the IL2 gene Effect of deficiency: Defect in TCR signaling

LCK Function: A tyrosine kinase associated with the cytoplasmic tails of CD4 and CD8 in T cells. Involved in the maturation, activation, and differentiation of $\mathrm{T}$ cells Effect of deficiency: Normal T-cell number, reduced regulatory T cells, impaired TCR signaling, and restricted T-cell repertoire

Vav1 Function: Required for T-cell activation and T-helper polarization to $\mathrm{T}_{\mathrm{H}} 2$ subsets Effect of deficiency: T-cell dysfunction

Rac2 Function: A member of the Rho family of GTPase, which are crucial regulators of cell signaling and actin cytoskeleton

Effect of deficiency: Reduced chemotaxis activity, reduced numbers of neutrophil granules, as well as morphological changes in secondary granules, defects in the development of B and T cells

ZAP70 Function: A member of the Syk family of tyrosine kinases, which play an important role in T-cell activation Effect of deficiency: Impaired T-cell function due to defective recruitment and activation of ZAP70

LRBA Function: A cytosolic protein that participates in multiple cellular functions such as vesicular trafficking, signal transduction, cytoskeleton assembly, transcriptional regulation, autophagy, and apoptosis Effect of deficiency: Hypogammaglobulinemia and reduced switched memory B cells, as well as various clinical manifestations, such as autoimmunity, enteropathy, and recurrent respiratory infections

ERK Function: A serine/threonine kinase that phosphorylates various substrates and plays important roles in cell proliferation, differentiation, migration, and survival

Effect of deficiency: Dysregulation of BCR-induced ERK activation in naïve and IgM memory B cells, blocking of BCR endocytosis and B-cell dysfunction, especially in CVID patients with the CD21 low phenotype

CARMA1/ Function: T- and B-cell activation through NF-kB activation after TCR and BCR cross-linking

CARD11 Effect of deficiency: Impaired B-cell differentiation and T-cell proliferation, reduced number of T regulatory cells and increased number of transitional B cells

Bob1 Function: A B cell-specific transcriptional co-activator that stimulates transcription in selected immunoglobulin genes

Effect of deficiency: Decreased B-cell production and activation, impaired germinal center formation, and reduced class-switched immunoglobulins

TLRS TLR9 Function: Recognition of DNA-containing CpG motifs derived from microbes and key roles in the activation of immune responses

Effect of deficiency: Normal number of B cells, but decreased circulating memory and

TLR7 switched memory CD27 $7^{+}$cells, decreased plasma cells and increased transitional B cells Function: Recognition of single-stranded RNA derived from microbes Effect of deficiency: Defective B-cell proliferation, lack cytokine production, impaired IgG and IgA production in both naïve and memory B cells. These defects are also seen in $\mathrm{pDCs}$, as they have been shown to fail to produce IFN- $\alpha$ in response to TLR ligands

$[73,179$,

Abbreviations: BCR, B-cell receptor; GTPase, guanosine triphosphatase; NF- $\kappa B$, nuclear factor kappa-light-chain-enhancer of activated B cells; pDCs, Plasmacytoid dendritic cells; TCR, T-cell receptor; TLR, Toll-like receptors. 
Table 3. Nuclear Defects in Patients With Common Variable Immunodeficiency

\begin{tabular}{|c|c|c|}
\hline Gene & Function & Ref \\
\hline $\begin{array}{l}N F K B(N F K B 1, \\
N F K B 2)\end{array}$ & $\begin{array}{l}\text { Function: NF- } \kappa \text { B signaling plays an important role in B-cell maturation, differentiation, } \\
\text { survival, class switching, and tolerance to self-antigens } \\
\text { Effect of deficiency: Defective development or maintenance of TFH cells, impaired T-cell } \\
\text { and NK-cell functions, reduced switched memory B-cell counts, (pan) hypogammaglobulinemia }\end{array}$ & [207-209] \\
\hline$I K Z F 1$ & $\begin{array}{l}\text { Function: A member of a family of hematopoietic zinc-finger transcription factors that play } \\
\text { key roles in B-cell lymphopoiesis and function. } \\
\text { Effect of deficiency: Panhypogammaglobulinemia, low B-cell number with a progressive loss } \\
\text { of serum immunoglobulins and B cells }\end{array}$ & [210] \\
\hline STAT1 & $\begin{array}{l}\text { Function: A member of the transcription protein family important in many biological processes } \\
\text { Effect of deficiency: Hypogammaglobulinemia, reduced switched memory and plasma cells, } \\
\text { increased proportion of naïve, CD21 } 1^{\text {low }} \text {, and transitional B cells, as well as reduced numbers } \\
\text { of IL-17-producing CD4 } 4^{+} \mathrm{T} \text { cells and T regulatory cells }\end{array}$ & [211] \\
\hline $\begin{array}{l}\text { IRF } 2 B P 2 \text { (interferon } \\
\text { regulatory factor } 2 \\
\text { binding protein 2) }\end{array}$ & $\begin{array}{l}\text { Function: A negative regulator of the NFAT transcription factor, role in the differentiation } \\
\text { and/or survival of memory B cells and plasmablasts } \\
\text { Effect of deficiency: Relative decrease in switched memory B cells, undetectable IgG2, } \\
\text { absent IgA and low IgM, decreased formation of B-cell plasmablasts }\end{array}$ & [212] \\
\hline NEIL1 & $\begin{array}{l}\text { Function: DNA glycosylases that participate in base excision repair and B-cell development } \\
\text { and function } \\
\text { Effect of deficiency: Increased naïve memory B cells }\left(\operatorname{IgD}^{+} \mathrm{CD} 27^{-}\right) \text {, reduced count of marginal } \\
\text { zone B cells }\left(\operatorname{IgD} \mathrm{CD}^{+} 27^{+}\right) \text {, almost complete absence of class-switched memory B cells, } \\
\text { and low level of immunoglobulins }\end{array}$ & [213] \\
\hline SEC61A1 & $\begin{array}{l}\text { Function: The major subunit of the Sec } 61 \text { complex, ie, the } 57 \text { main polypeptide-conducting } \\
\text { channels in the endoplasmic reticulum membrane; strongly induced during plasma cell differentiation } \\
\text { Effect of deficiency: Impaired plasma cell homeostasis without interfering with B-cell development, } \\
\text { activation, or memory formation }\end{array}$ & [214] \\
\hline$C D 70$ & $\begin{array}{l}\text { Function: Participation in T-cell expansion and survival, germinal center formation, B-cell } \\
\text { activation, antibody production, and NK-cell function } \\
\text { Effect of deficiency: Increased susceptibility to EBV-induced disease as well as impairment in } \\
\text { T- and B-cell differentiation, hypogammaglobulinemia, poor antibody responses to vaccinations, } \\
\text { and/or reduced percentage of switched memory B cells }\end{array}$ & [213] \\
\hline ATP6AP1 & $\begin{array}{l}\text { Function: Encodes the accessory protein Ac } 45 \text { of the V-ATPase } \\
\text { Effect of deficiency: Hypogammaglobulinemia, problem in B-cell differentiation }\end{array}$ & [215] \\
\hline TTC37 & $\begin{array}{l}\text { Function: Encodes members of the human Ski complex, which plays a role in exosomal RNA } \\
\text { degradation } \\
\text { Effect of deficiency: Specific antibody deficiency with impairment of humoral memory }\end{array}$ & [216] \\
\hline TRNT1 & $\begin{array}{l}\text { Function: A template-independent RNA polymerase that is essential for maturation of both } \\
\text { nuclear and mitochondrial transfer RNAs } \\
\text { Effect of deficiency: B-cell immunodeficiency }\end{array}$ & [217] \\
\hline PTEN & $\begin{array}{l}\text { Function: Downregulation of AKT signaling in the mTOR pathway, which is critical for cell } \\
\text { survival, proliferation, growth, and metabolism } \\
\text { Effect of deficiency: Hypogammaglobulinemia, reduced numbers of memory B cells and } \\
\text { class-switched memory B cells }\left(\mathrm{CD} 27^{+} \mathrm{IgM}^{-} \mathrm{IgD}^{-}\right)\end{array}$ & [218] \\
\hline
\end{tabular}

Abbreviations: EBV, Epstein-Barr virus; NF- $\kappa B$, nuclear factor kappa-light-chain-enhancer of activated B cells; NFAT, nuclear factor of activated T cells; $\mathrm{TFH}, \mathrm{T}$ follicular helper cells.

of DNA methylation in the switched and nonswitched memory B cells of the patient when compared with the healthy sibling. Furthermore, hypermethylation was observed in genes such as PIK3CD, BCL2L1, RPS6KB2, TCF3, and KCNN4 in B cells, and demethylation during the transition from naive to memory cells was impaired. This observation revealed a novel mechanism responsible for the defective generation of memory cells in CVID patients [17]. Using an equine CVID model, disturbance of methylation in the form of hypermethylation of
PAX5 was shown to block B-cell development, reduce B-cell numbers, and lead to the development of late-onset CVID [22].

Other factors implicated in the epigenetic regulation of B cells are ncRNAs [26], which exert their regulatory functions by posttranscriptional changes in mRNA or by influencing DNA transcription [26]. miRNAs, a subgroup of short ncRNAs that mainly repress gene expression, contribute to the regulation of different stages of B-cell development. While studies on the role of miRNAs in the pathogenesis 
of human CVID are ongoing, mouse models have already demonstrated the importance of these molecules for $\mathrm{T}$ - and B-cell development [27]. Importantly, knockout mice lacking miR-142 [23] or miRNA-155 [27] exhibit immunological features similar to those observed in CVID patients.

Histone and chromatin modifications are an epigenetic mechanism that might also be involved in the pathogenesis of CVID. Defects in histone and chromatin modification enzymes have been described in patients with Kabuki syndrome, a complex multisystem syndrome that includes hypogammaglobulinemia, reduced naïve and switched memory $\mathrm{B}$ cells, and an increase in the CD21 $1^{\text {low }} \mathrm{B}$-cell population, all of which are often found in patients with CVID. In Kabuki syndrome, the B-cell differentiation defect was shown to be associated with an impaired histone modification process, which is fundamental for correct B-cell development [28].

\section{Microbiome Dysbiosis}

The human microbiome interacts with the systemic immune system via immune cells and bacteria that can cross the gut epithelium, thus exposing the systemic immune system to microbial components [29]. Bacterial products such as lipopolysaccharide can activate the immune response through recognition of microbe-associated molecular patterns by the innate immune system [30]. Microbial dysbiosis may lead to overgrowth of proinflammatory bacteria or a decrease in antiinflammatory bacteria, which subsequently leads to further imbalance in the immune system [31].

Importantly, CVID patients have extensive microbial dysbiosis with reduced $\alpha$ diversity and differences in the taxonomic profile when compared with patients with inflammatory bowel disease. This reduction in $\alpha$ diversity in CVID patients is associated with raised T-cell activation markers, including lipopolysaccharide and SCD25, and decreased levels of plasma IgA, suggesting that the altered gut microbiota profile could modulate gut permeability with subsequent elevation of lipopolysaccharide and sCD25 and decreased IgA, alongside chronic immune activation [32]. Nevertheless, attributing causality to microbial changes due to the presence of low IgA level and impaired epithelial gut barrier remains challenging, and further research in this field is clearly needed.

Table 4. Abnormalities and Functions of Immune Cells in Patients With Common Variable Immunodeficiency

\begin{tabular}{|c|c|c|c|}
\hline Cell Type & Subsets & Increased/Decreased & Ref \\
\hline B cell & $\begin{array}{l}\text { Transitional B cells } \\
\mathrm{CD} 21^{\text {low }} \mathrm{B} \text { cells } \\
\text { IgM memory B cells }\left(\mathrm{CD} 19^{+} / \mathrm{CD} 27^{+}\right) \text {, } \\
\text { Class-switched memory B cells } \\
\left(\mathrm{CD} 19^{+} / \mathrm{CD} 27^{+} / \mathrm{IgD}^{-} / \mathrm{IgM}^{-}\right) \\
\text {Plasma cells }\end{array}$ & $\begin{array}{l}\text { Increased } \\
\text { Increased } \\
\text { Decreased } \\
\text { Decreased } \\
\text { Decreased }\end{array}$ & $\begin{array}{l}{[42]} \\
{[43]} \\
{[34]} \\
{[39]} \\
{[40,219]}\end{array}$ \\
\hline T cell & $\begin{array}{l}\text { Naïve } \mathrm{CD}^{+} \mathrm{T} \text { cells } \\
\text { Effector memory } \mathrm{CD} 4^{+} \mathrm{T} \text { cells } \\
\text { Central memory } \mathrm{CD} 4^{+} \mathrm{T} \text { cells } \\
\text { Activated } \mathrm{CD} 4^{+} \mathrm{T} \text { cells } \\
\mathrm{T}_{\mathrm{H}} 1 / \mathrm{T}_{\mathrm{H}} 2 \\
\mathrm{~T}_{\mathrm{H}} 17 \text { cells } \\
\text { Follicular T helpers }\left(\mathrm{CD} 4^{+} / \mathrm{CXCR}^{+}\right) \text {cells } \\
\mathrm{T} \text { regulatory cells } \\
\text { Naïve } \mathrm{CD} 8^{+} \mathrm{T} \text { cells } \\
\text { Effector memory } \mathrm{CD} 8^{+} \mathrm{T} \text { cell } \\
\text { Central memory CD }{ }^{+} \mathrm{T} \text { cell } \\
\text { Activated CD } 8^{+} \mathrm{T} \text { cells } \\
\gamma \delta+\mathrm{T} \text { cells }\end{array}$ & $\begin{array}{l}\text { Decreased } \\
\text { Increased (in all } 3 \text { groups } \mathrm{Ia} / \mathrm{Ib} / \mathrm{II} \text { ) } \\
\text { Increased (in all } 3 \text { groups } \mathrm{Ia} / \mathrm{Ib} / \mathrm{II} \text { ) } \\
\text { Increased } \\
\text { Trend towards } \mathrm{T}_{\mathrm{H}} 1 \text { or } \mathrm{T}_{\mathrm{H}} 2 \\
\text { Decreased } \\
\text { Increased/ Decreased } \\
\text { No difference between the patients } \\
\text { and healthy control/ Decreased } \\
\text { Decreased } \\
\text { Increased (in all } 3 \text { groups } \mathrm{Ia} / \mathrm{Ib} / \mathrm{II} \text { ) } \\
\text { Increased (in group I) } \\
\text { Increased } \\
\text { Increased }\end{array}$ & $\begin{array}{c}{[46,48]} \\
{[46]} \\
{[46]} \\
{[46]} \\
{[50-52,220]} \\
{[53]} \\
{[55,56,58]} \\
\\
{[48,60,61,67]} \\
{[48]} \\
{[46,48]} \\
{[46]} \\
{[66,67]} \\
{[70,221,222]}\end{array}$ \\
\hline Dendritic cell & DCs cells & Decreased & {$[74,223,224]$} \\
\hline Monocyte/Macrophage & IL-12 ${ }^{+}$monocytes & Increased & {$[77]$} \\
\hline \multirow[t]{2}{*}{ Innate lymphoid cell } & $\begin{array}{l}\text { IL- } 17^{+} \mathrm{CD} 127+\mathrm{Thy} 1^{+} \mathrm{Lin}^{-} \text {cells } \\
\mathrm{Lin}-\mathrm{CD} 127^{+} \text {cells producing IFN-y, } \\
\text { IL-17A and IL-22 }\end{array}$ & $\begin{array}{l}\text { Decreased } \\
\text { Increased }\end{array}$ & $\begin{array}{l}{[54]} \\
{[225]}\end{array}$ \\
\hline & $\begin{array}{l}\mathrm{CD} 3^{-} \mathrm{CD} 16^{+} \mathrm{CD} 56^{+} \mathrm{CD} 28^{+} \mathrm{NK} \text { cells } \\
\mathrm{CD}^{-} \mathrm{CD} 16^{+} \mathrm{CD} 56^{+} \mathrm{CD} 28^{-} \mathrm{NK} \text { cells }\end{array}$ & $\begin{array}{l}\text { Increased } \\
\text { Decreased }\end{array}$ & $\begin{array}{l}{[83]} \\
{[83]}\end{array}$ \\
\hline$N K T$ & NKT cells & $\begin{array}{l}\text { No difference between the patients } \\
\text { and healthy control. }\end{array}$ & {$[85]$} \\
\hline$i N K T$ & iNKT cells & Decreased & {$[86]$} \\
\hline
\end{tabular}

Abbreviations: iNKT, invariant natural killer T cell; NKT, natural killer T cell. 


\section{Immune Cell Abnormalities}

Defects in the adaptive and innate immune system, and in particular abnormal B-cell and T-cell values have been reported in CVID patients. Although the classic immunological defect in CVID is plasma cell abnormalities, alterations of other B-cell subsets are not uncommon. Table 4 gives an overview of the immune cell abnormalities in CVID to date.

\section{$B$-Cell Subsets}

B-cell development involves sequential steps of maturation that is initiated in the bone marrow and completed in peripheral compartments. Immature B cells pass through transitional stages and become either marginal zone B cells or naïve peripheral follicular B cells. In germinal centers, follicular B cells differentiate to switched memory B cells and antibody secreting plasma cells, whereas marginal zone B cells evolve to IgM memory B cells [33,34]. Most studies show that almost $90 \%$ of CVID patients have normal B-cell counts, $[35,36]$, indicating that the major defect is likely related to alterations of the terminal stages of B-cell differentiation. Furthermore, several groups, including our own, have shown that disturbed B-cell subsets could result from an increase of terminal B-cell apoptosis $[37,38]$. Impaired antibody production despite normal B-cell counts also suggests a defect in the differentiation of B cells into memory and plasma cells in many CVID patients [35].

Several studies have reported decreased IgM memory B cells $\left(\mathrm{CD} 19^{+} / \mathrm{CD} 27^{+}\right)$, class switched memory B cells $\left(\mathrm{CD} 19^{+} / \mathrm{CD} 27^{+} /\right.$ $\left.\operatorname{IgD}^{-} / \operatorname{IgM}^{-}\right)$, and plasma cells in CVID patients $[34,39,40]$. Since correct germinal center formation is essential for the development of switched memory B cells in secondary lymphoid organs, it seems that the reduction in switched memory B cells is closely related to the impaired germinal center reaction. In contrast, profound expansion of the transitional B-cell pool has been observed in 2 siblings with CVID disorder (especially BAFF-R deficiency) due to a block in the transition from $\mathrm{T} 1$ to T2 cells [41-43]. Furthermore, a subgroup of CVID patients manifests with the expansion of a special subset of B cells, ie, $\mathrm{CD} 21^{\text {low }} \mathrm{B}$ cells, which is distinct from other B-cell subsets, as it is characterized by low expression of CD21 and CD38 simultaneously [43]. It has been demonstrated that expansion of this subset is associated with an abundance of IFN- $\gamma$-producing $\mathrm{CD}^{+} \mathrm{CXCR}^{+} \mathrm{T}$ follicular helper (TFH) cells and immune dysregulation in CVID patients [44].

The characterization of signaling pathways that are essential for B-cell differentiation and class-switch recombination (CSR) has been evaluated by Taraldsrud et al [45], who found that constitutive phosphorylation levels of signal transducer and activator of transcription (STAT 3, -5 , and -6), phosphoinositide phospholipase C- $\gamma$, Erk, and Syk were significantly increased in B cells of selected CVID patients with noninfectious complications. In the future, the combination of surface marker determination and the kinase phosphorylation pattern may enable us to develop a model able to predict the occurrence of noninfectious complications in CVID patients.

\subsection{T-Cell Subsets}

The T-cell abnormalities reported in CVID patients are broad and include total numbers, percentages, surface markers, and function of various T-cell subpopulations [5]. Some studies showed a reduction in numbers for total, naïve, and memory $\mathrm{CD}^{+} \mathrm{T}$ cells, and recent thymic emigrants and an increase in activated $\mathrm{CD}^{+} \mathrm{T}$ cells [46]. Decreased thymic output, enhanced T-cell turnover, and spontaneous apoptosis lead to reduced $\mathrm{CD}^{+} \mathrm{T}$-cell counts [46], whereas the observed increase in activation of $\mathrm{CD}^{+} \mathrm{T}$ cells might be due to low regulatory B-cell (Breg) numbers and defective Breg responses after T-cell stimulation [47]. It has been demonstrated that CVID patients with considerably reduced $\mathrm{CD}^{+} \mathrm{T}$-cell counts are more likely to develop autoimmunity and lymphoproliferation, indicating that there is a strong correlation between the frequency of naïve $\mathrm{CD} 4^{+} \mathrm{T}$ cells and clinical manifestations. However, despite T-cell abnormalities reported in CVID patients based on discrepancies in the different criteria for diagnosis, it is not clear whether patients with such defects should be considered affected with CVID or with late-onset combined immunodeficiency or other forms of combined immunodeficiencies [48,49].

The role of the different T-helper subsets for the pathophysiology or development of clinical manifestations in CVID patients remains controversial, and it has been reported that levels of type 2 helper $\left(\mathrm{T}_{\mathrm{H}} 2\right)$ cytokines such as IL-4 and IL-10 are significantly elevated in CVID patients, whilst this increase was not observed for $\mathrm{T}_{\mathrm{H}} 1$ cytokines [50]. Similarly, the serum level of CD30 (an indicator of $\mathrm{T}_{\mathrm{H}} 2$ cytokine production) is increased in CVID patients [50], suggesting that this population might be skewed towards $\mathrm{T}_{\mathrm{H}} 2$ responses. However, other studies report excessive $T_{H} 1$ responses in CVID patients $[51,52]$. This discrepancy is likely due to differences in the etiology of CVID, differences in the composition of patient cohorts, and differences in experimental methodology.

$\mathrm{T}_{\mathrm{H}} 17$ cells have also been investigated in CVID patients. $\mathrm{T}_{\mathrm{H}} 17$ cells and their related cytokines IL-17A, IL-17F, IL-22, and IL-21 are involved in host defense against extracellular bacterial and fungal infections and also play an important role in inflammatory diseases. Barbosa et al [53] reported a decrease in the frequency of circulating $T_{H} 17$ cells in CVID patients. Moreover, another study demonstrated a reduction in $\mathrm{T}_{\mathrm{H}} 17$ cell-specific gene expression in CVID patients when compared with healthy controls [54]. A negative correlation between $T_{H} 17$ cells, probably due to its regulatory role in the appropriate function of the germinal center, and the expansion of activated CD2 $1^{\text {low }} \mathrm{B}$ cells have been observed $[36,43,44]$. As for TFH in CVID patients, some studies have identified increased TFH counts $[55,56]$, whereas a decrease in TFH cells has been observed in both ICOS-deficient mice and patients $[57,58]$. Since TFH cells express ICOS on their surface, decreased TFH counts are the logical consequence in patients with ICOS deficiency.

Regulatory T cells (Tregs) are important regulators of the immune system and play a crucial role in the maintenance of self-tolerance [59]. Kutukculer et al [60] did not observe significant differences between the percentages and absolute counts of Treg in CVID patients when compared with healthy controls and therefore concluded that Treg cells are not relevant in the pathogenesis of CVID. However, the results of other studies suggest that a reduction in Treg counts can influence disease manifestations and indicate a correlation between 
Treg counts and autoimmune manifestations, granulomatous lesions, and splenomegaly $[61,62]$. Furthermore, sorted Treg cells from patients with CVID are less effective in suppressing proliferation of autologous and allogenic effector $\mathrm{CD}^{+} \mathrm{T}$ cells than CVID patients without autoimmunity [63], and the decrease in Treg cells correlates with the expansion of CD2 $11^{\text {low }}$ B cells in CVID patients with autoimmunity [64].

Similar to $\mathrm{CD}^{+} \mathrm{T}$ cells, the frequency of $\mathrm{CD} 8^{+} \mathrm{T}$-cell subsets has been shown to decline. Naïve and effector memory $\mathrm{CD}^{+} \mathrm{T}$-cell numbers are reduced, whereas higher percentages of activated $\mathrm{CD} 8^{+} \mathrm{T}$ cells have been reported $[48,65,66]$. Studies show that CD $8^{+} \mathrm{HLA}-\mathrm{DR}^{+}, \mathrm{CD} 8^{+} \mathrm{CD} 38^{+}$, and $\mathrm{CD} 8^{+} \mathrm{CD} 38^{+} \mathrm{HLA}-\mathrm{DR}^{+} \mathrm{T}$-cell counts are higher in CVID patients and that this increase is restricted to patients with clinical complications, including autoimmune disease, splenomegaly, lymphoid proliferation, and granulomatous disease [65]. Moreover, higher expression levels of granzyme $\mathrm{B}$ in $\mathrm{CD}^{+} \mathrm{T}$ cells correlate with autoimmune manifestations in CVID patients [67]. Viallard et al [68] showed that patients with low $\mathrm{CD} 27^{+} \mathrm{B}$-cell counts had higher percentages of HLA-DR CD8 $\mathrm{T}^{+}$cells with a differentiated effector phenotype, thus further confirming a higher activation status of $\mathrm{CD}^{+}$cells in CVID patients [69]. Finally, Paquin-Proulx et al [70] found a specific subset of $\gamma \delta$ T cells expanded in CVID patients. Although they suggested that this deviation in $\gamma \delta$ T-cell subsets is a general feature of CVID patients, further studies are needed to confirm this observation.

\section{Dendritic Cel/s}

Dendritic cells (DCs) play an important role in the induction of T-cell responses, as well as in the differentiation of naïve B cells to plasma cells. Studies on DCs in CVID patients have shown a progressive decline of these cells, as well as maturation and function abnormalities [71]. In this regard, the expression of maturation and costimulatory molecules such as CD80, CD86, and HLA-DR and the production of IL-12 were lower in CVID patients [71,72]. Furthermore, decreased IFN- $\alpha$ production upon TLR-9 stimulation in plasmacytoid DCs has been demonstrated $[63,73]$. In contrast, Taraldsrud et al [74] reported that DCs of CVID patients have a normal response to TLR-7 and TLR-9 and viral stimulation and have normal numbers of DC progenitor cells in bone marrow [74]. Based on the prominent role in presenting antigens to $\mathrm{T}$ cells and initiation of primary immune responses, abnormalities in DCs may lead to a defect in the generation of antigen-specific $\mathrm{CD}^{+} \mathrm{T}$ cells and to impaired antibody production, as in CVID patients.

\section{Monocytes/Macrophages}

Monocytes from CVID patients exhibit significantly increased generation of reactive oxygen species, which might result in specific clinical manifestations, including malignancies, autoimmune disorders, and some acute and chronic pulmonary diseases [75]. Aukrust et al [76] suggested that persistently increased TNF levels and TNF receptor expression might contribute to the activation of monocytes/macrophages. Moreover, it has been demonstrated that increased IL-12 production in $\mathrm{CD} 14^{+}$monocytes results in skewed T-cell responses toward $\mathrm{T}_{\mathrm{H}} 1$. In addition, overexpression of IL-12 leads to the upregulation of IFN- $\gamma$ in T-cell subsets and subsequently skews the immune system away from the $T_{H} 2$ response to a $T_{H} 1$ response [77]. Thus, it seems that the altered cytokine profile in monocytes may contribute to the enhanced $\mathrm{T}_{\mathrm{H}} 1$ profile and thus to defective antibody production in a selected group of CVID patients.

In the absence of additional cytokines, the tendency of monocytes (mainly CD83-negative monocytes) from CVID patients to form giant cells is almost twice as strong as in normal cells. However, the excess of cytokines such as IL-4, granulocyte-macrophage colony-stimulating factor, IFN- $\gamma$, and TNF- $\alpha$ contribute to a 5 -fold increased monocyte fusion index in CVID. A higher fusion index contributes to formation of granuloma (a lymphoproliferative complication) and is related to chronic inflammation (eg, inflammatory cytokines, particularly IFN- $\gamma$ and TNF) and lymphocyte concentration. Of note, in vitro, the fusion rate of monocytes treated with immunoglobulin-based products can be increased, thus raising the debate of whether this standard treatment is involved in the risk of granulomatous disease, possibly by enhancing Fc $\gamma$ RI expression [78].

\section{Innate lymphoid cells}

Innate lymphoid cells (ILCs) are a group of immune effector cells characterized by lymphoid morphology but lacking the B- and T-cell receptor. They play an important role in innate immunity, tissue development, and cytokine production [79]. Based on phenotypic and functional characteristics, ILCs are classified into 3 major groups. Group 1 comprise NK cells and other noncytotoxic ILCs, defined by T-bet expression and IFN- $\gamma$ production; group 2 express GATA-3 and produce type 2 cytokines such as IL-4, IL-5, and IL-13; group 3 contain the transcription factor ROR $\gamma \mathrm{T}$ and are able to produce IL-17 and IL-22 [79]. A recent study demonstrated that the numbers of IL- $17^{+} \mathrm{CD} 127^{+}$Thy $-1^{+}$Lin-ILCs are decreased in CVID patients [54]. Conversely, another study found a significantly expanded population of Lin-CD $127^{+}$cells producing IFN- $\gamma$, IL-17A, and IL-22, and it has been suggested that the expansion of these cells is characteristic of CVID patients with inflammatory manifestations [80].

With respect to group $1 \mathrm{ICLs}$, the frequency and function of NK cells have also been evaluated in CVID patients. NK cells are a component of the innate immune system and play an important role in the killing of the tumor and virally infected cells $[81,82]$. Kutukculer et al [83] reported increased numbers of $\mathrm{CD}^{-} \mathrm{CD} 16^{+} \mathrm{CD} 56^{+} \mathrm{CD} 28^{+} \mathrm{NK}$ cells, whereas $\mathrm{CD} 28^{-} \mathrm{NK}$ cells were significantly decreased in CVID patients. This increase could be related to the presence of a compensatory mechanism for protection against tumor development and viral infections, as a high frequency of bacterial infections and noninfectious disease, especially viral infections and tumor development, has been observed in CVID patients with NK deficiency [82].

Group $2 \mathrm{CD}_{117^{+}}$ILCs have a role in the generation of antibody production. It was recently reported that the number of these cells is reduced in patients with CVID (with an impaired response to IL-2, -7, -25, and -33) [84]. Disease in these patients manifests with an increased prevalence of 
chronic enteropathy and an immunologic profile of lower numbers of peripheral marginal zone-like B cells [84].

\section{NKT Cells}

NKT cells are lymphocytes with a rearranged Va14-Ja18 TCR that recognizes glycolipids. They are able to produce $\mathrm{T}_{\mathrm{H}} 1$ and $\mathrm{T}_{\mathrm{H}} 2$ cytokines upon stimulation. Carvalho et al [85] demonstrated that NKT cell subsets are imbalanced in CVID patients, as the frequency of $\mathrm{CD}^{+}{ }^{+} \mathrm{NKT}$ cells is higher than that of $\mathrm{CD}^{+}$NKT cells. However, they also found that there was no difference in the frequency of circulating NKT cells between the patients and healthy controls. In contrast, a study on iNKT cells identified a marked decrease in the proportion of these cells that was associated with low or absent switched memory B cells, thus supporting a potential correlation between iNKT-cell and B-cell function [86].

\section{Clinical Manifestations}

\section{Infections}

Infections are the most typical clinical manifestations of CVID and involve the respiratory and gastrointestinal tracts [87]. The upper and lower respiratory tract are the most common sites of infection and contribute significantly to morbidity and mortality in CVID patients [88]. Streptococcus species, Haemophilus species, Moraxella catarrhalis, Neisseria meningitides, and Staphylococcus species are the bacteria causing infections in CVID patients $[88,89]$. Moreover, viral pathogens such as Rhinovirus and Herpes zoster and Mycoplasma species are more prevalent and even more persistent in CVID [90]. Although opportunistic infections by Pneumocystis jiroveci and Cytomegalovirus are not characteristic of CVID and should be questioned, they can be found in a subgroup of patients with a diagnosis of CVID and a low $\mathrm{CD}^{+}{ }^{+}$T-cell count [91].

Bronchiectasis and interstitial lung disease are major lung complications that manifest after recurrent and severe lung infections $[92,93]$. In addition, recurrent sinusitis, bronchitis, and otitis media are found in half of the patients. Immunoglobulin replacement therapy has an important role in decreasing the frequency of infection, yet susceptibility to infections remains problematic [89]. This approach modifies the natural course of the disease, although mainly in invasive infections, while the incidence of respiratory infections, including pneumonia, may depend on several factors, such as late diagnosis with the development of bronchiectasis and immune dysregulation [88].

Gastrointestinal tract infections manifest in form of chronic or acute diarrhea [94]. Typical histopathology findings in the intestinal tissue of CVID patients are deep follicular lymphoid hyperplasia and reduced plasma cell counts. Giardia lamblia is the most commonly identified pathogen, followed by Campylobacter jejuni and Salmonella species. These infections are characteristic of patients with undetectable serum IgA levels, and intravenous immunoglobulin replacement therapy has not led to consistent improvement of gastrointestinal symptoms $[95,96]$.
Despite the known increased susceptibility to infection, there is no significant difference between the prevalence of Helicobacter pylori infection in CVID when compared with healthy individuals. One potential explanation is the relatively common prescription of prophylactic and therapeutic antibiotics in this patient group, which may collaterally prevent $\mathrm{H}$ pylori infection $[95,97,98]$. However, given the role of $H$ pylori infection in the development of gastric dysplasia and gastric cancer in CVID, this population should be screened $[96,99]$.

Regarding mild infections in CVID patients, some patients experience infections but no noninfectious complications. According to the classification of clinical phenotype by Chapel et al [100], these patients are categorized as "infection only" phenotype. Milder clinical severity and longer survival in this population could be due to the presence of a compensatory mechanism in memory B-cell generation and IgG production after coculture of PBMCs with anti-CD40 $0^{+}$, IL-21, and IL-4 [101].

\section{Autoimmunity}

Autoimmune manifestations are common (10\%-30\%) among PID patients [102], and autoimmunity is present in $21 \%$ to $42 \%[103,104]$. Physicians should consider a diagnosis of CVID in patients with autoimmune features in order to prevent diagnostic and therapeutic delays [105]. Autoimmune cytopenias (idiopathic thrombocytopenic purpura, autoimmune hemolytic anemia, and autoimmune neutropenia) are the most common and potentially severe manifestations [106,107], while other autoimmune manifestations, such as rheumatologic autoimmune disorders, are also observed in these patients [108-112].

Autoimmunity is the aberrant response of the immune system to self-antigens that occurs when self-tolerance is impaired. Several factors that influence induction of T-cell tolerance, such as lower T-cell and Treg numbers and aberrations in cytokine secretion, have been described as mechanisms leading to autoimmunity in CVID patients [67,113]. CSR and somatic hypermutation defects, increased levels of BAFF, impaired TLR, and abnormalities in lymphoid cell subsets have been reported in CVID patients and are likely associated with the development of autoimmune manifestations [111,114-116]. It is notable that despite the low serum level of immunoglobulins and poor specific antibody response in CVID patients, autoantibodies are often found in a particular group of CVID cases [117]. Although intriguing, these sometimes counterintuitive observations underscore the need for further research to reveal the underlying mechanisms leading to autoimmunity in CVID.

\section{Lymphoproliferation and Malignancy}

An increased risk of malignancy has been reported in CVID patients [118]; however, the precise incidence and mechanism of this association are still unclear. It has been estimated that the incidence of malignancy among CVID patients is almost $2.5 \%$ when the age at onset of symptoms is $<16$ years and almost $8.5 \%$ among patients diagnosed at an older age [118]. CVID patients with polyclonal lymphadenopathy have an increased risk of lymphoid malignancies, with the overall risk for lymphoid malignancies (mostly extranodal non-Hodgkin B-cell lymphoma) being $2 \%-10 \%$ for CVID patients $[9,107]$. 
Additionally, CVID patients are prone to develop malignant gastric cancers $[103,119]$. Impaired immunity to carcinogenic pathogens such as Epstein-Barr virus and H pylori potentially contributes to this. A 10 -fold risk of gastric cancer has been reported in CVID [120], although this ratio has recently decreased [9], potentially owing to increased use of antibiotics, which at least partially treat and control $H$ pylori infection. Consequently, chronic atrophic gastritis and metaplasia affecting the stomach (the main predisposing factors for gastric adenocarcinoma in CVID patients) are reduced.

\section{Enteropathy}

A selected group of CVID patients experience complex gastrointestinal disorders refractory to conventional treatments, resulting in significant weight loss and malnutrition that in some cases require long-term parenteral feeding [107,121]. Histopathology in tissue samples obtained from patients with small-bowel disease commonly shows villous atrophy and inflammatory lymphocytic infiltrates [95,121]. Besides the obvious nutritional, gastrointestinal, and infectious complications shared with many other PID patients, CVID patients with this specific enteropathy phenotype are prone to complications as a result of changes in bone mineral density, granulomatous disease and lymphopenia and exhibit overall higher mortality [122,123].

\section{Asthma and Allergic Diseases}

Patients with CVID and IgA deficiency are predisposed to develop atopic conditions, probably owing to mucosal immune defects, as well as immune dysregulation with a skew towards a $\mathrm{T}_{\mathrm{H}} 2$ phenotype [124]. However, data regarding the prevalence of atopic diseases in CVID are incomplete, and only a few reports are available on the incidence of asthma and allergic disorders in CVID patients [124,125]. According to currently available data, the prevalence of allergic disorders (including asthma, allergic rhinitis, atopic dermatitis, allergic eczema, food allergy, urticaria, allergic conjunctivitis, and drug allergy) ranges from $12 \%$ to $42 \%$ in the different CVID cohorts $[124,126]$. This discrepancy could be explained by factors such as sample size, underlying genetic defects, and ethnic composition. It seems that immune dysregulation, major histocompatibility complex haplotypes, impaired IgA response to luminal allergen challenge, high IgE level (because of a compensatory mechanism for decreasing other antibody isotypes), and persistent pulmonary infections are major causes of asthma and other atopic diseases in CVID patients [124]. Similar to other complications, a high degree of suspicion and prompt diagnosis of atopic disorders are important when caring for CVID patients, as this will likely impact their management and quality of life.

\section{Other Clinical Findings}

Neurologic and liver diseases are less commonly reported in CVID patients [127]. Infectious etiologies of the nervous system have been described in 43 cases and represent the largest class of neurologic dysfunction [128,129], followed by autoimmune/inflammatory myelitis $[130,131]$.
Neuroendocrine alterations [132,133] and nutritional deficiencies (vitamin E and B12 deficiency) have been reported but are generally uncommon $[134,135]$. Almost $10 \%$ of CVID patients manifest significant liver abnormalities, with an increase in alkaline phosphatase levels [136]. Primary biliary cholangitis, granulomatous liver disease [137], and idiopathic noncirrhotic portal hypertension (including nodular regenerative hyperplasia) are the most commonly observed manifestations in CVID patients [136,138].

\section{Diagnosis}

CVID comprises a broad phenotype with heterogeneous clinical and immunological features, thus leading to diagnostic difficulties and delays. Maintaining a high index of suspicion for CVID in patients with complex clinical manifestations and following established diagnostic criteria can help to establish a timely and precise diagnosis.

In general, hypogammaglobulinemia and recurrent infections are the hallmarks of a diagnosis of CVID [139]. Diagnostic criteria were proposed by the European Society for Immunodeficiencies (ESID) in 1999 and redefined in later years based on both laboratory findings and clinical symptoms [140]. The newest ESID criteria for CVID diagnosis are illustrated below:

At least 1 of the following:

- increased susceptibility to infection

- autoimmune manifestations

- granulomatous disease

- unexplained polyclonal lymphoproliferation

- affected family member with antibody deficiency

- AND marked decrease in $\mathrm{IgG}$ and marked decrease in IgA with or without low IgM

- AND at least 1 of the following:

- poor antibody response to vaccines (and/or absent isohemagglutinins)

- low switched memory B cells $(<70 \%$ of age-related normal value)

- AND secondary causes of hypogammaglobulinemia have been excluded

- AND diagnosis is established after the fourth year of life (although symptoms may be present earlier)

- AND no evidence of profound T-cell deficiency, defined as 2 of the following:

- CD4 cells/ $\mu \mathrm{L}: 2-6$ years $<300,6-12$ years $<250$, $>12$ years $<200$

- \% naive CD4: 2-6 years $<25 \%, 6-16$ years $<20 \%$, $>16$ years $<10 \%$

- T-cell proliferation absent

In practical terms, a family history and physical examination are helpful when differentiating between a patient with CVID and children with other risk factors predisposing them to recurrent infections. Based on the history and physical examination, a laboratory investigation should be performed, although this must be supplemented by immune function testing [141]. All screening for CVID must include a physical examination. However, clinical symptoms can vary from patient to patient, even among affected family members with identical mutations in the same gene [142- 
144]. If physical examination and the clinical history lead to a suspicion of PID, a primary paraclinical evaluation should be undertaken (Figure).

\section{Laboratory and Paraclinical Evaluations}

Initial evaluation: The most useful first-line immunological investigations that target CVID and most common CVID-like entities include a complete blood count with differential, lymphocyte subset analysis, and measurement of serum immunoglobulin. These tests can identify children who need further testing and referral to a subspecialist [145]. Patients with CVID have low serum Ig levels and/or decreased response to vaccination [146]. Since serum Ig levels vary with age, age-specific cutoffs should be used when performing the immunoglobulin assay. Protein loss should also be considered in patients with low Ig in serum; therefore, when this is suspected, serum albumin levels should be checked, because low albumin suggests protein loss through the kidney or malabsorption of the protein in the bowel. Titers of $\mathrm{IgG}$ antibody to vaccine antigens can be checked to determine specific antibody response. Both protein and polysaccharide antigens are commonly used for evaluation [147]. A vaccine with protein antigens can be checked at all ages, whereas immunization with polysaccharide antigens should only be evaluated if

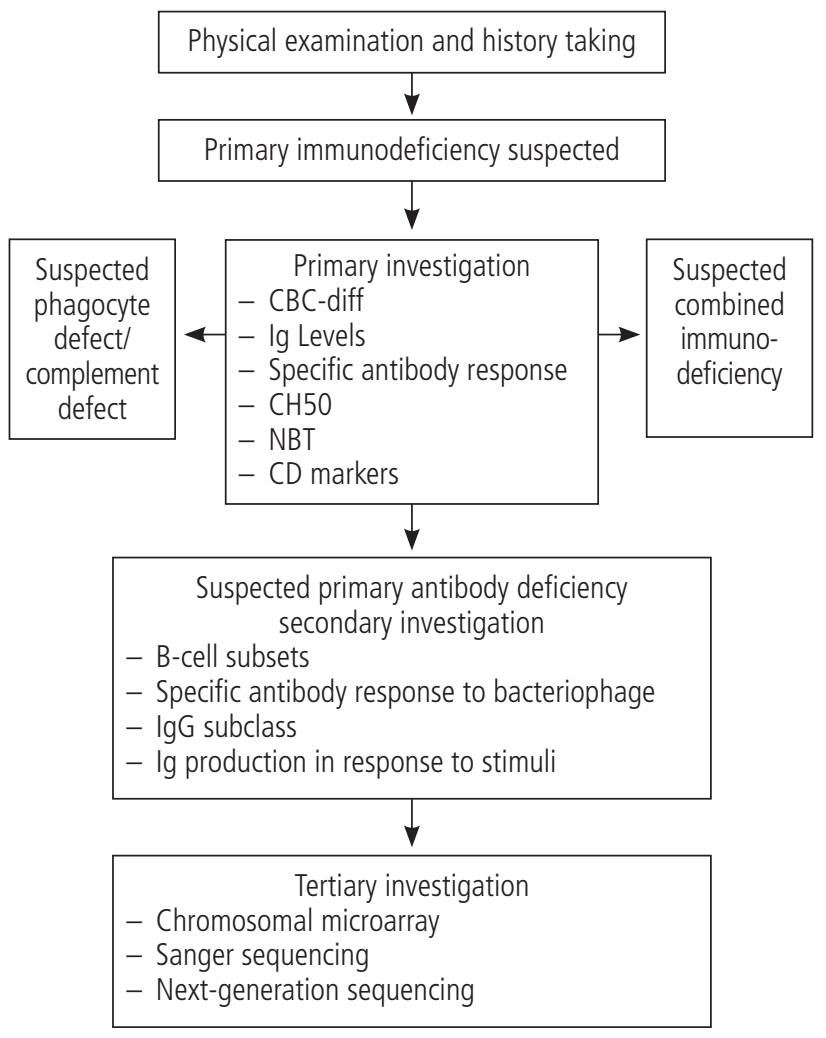

Figure. General approach for the diagnosis of common variable immunodeficiency. After physical examination and history-taking, the physician should evaluate patients with suspected primary immunodeficiencies in 3 steps (initial, secondary, and tertiary). the patient is 2 years or older. If the physician is using a conjugated pneumococcal vaccine, IgG antibody titers against specific serotypes should be measured [146].

Secondary evaluation: In addition to the global assessment of immune development through measurement of nonspecific features, such as serum immunoglobulin levels and leukocyte and lymphocyte subpopulations, evaluation of the specific immune response is essential. When screening tests reveal abnormalities associated with humoral immunity, advanced tests are recommended. These include IgG subclass analysis, flow cytometry to enumerate B-cell subsets (eg, naive and switched memory cells), in vitro immunoglobulin production in response to mitogens or other stimuli, and specific antibody response to immunization with $\phi X 174$ [148].

Tertiary evaluation: Genetic testing plays a vital role in the diagnosis of CVID. The various available tools include molecular and cytogenetic tests. Currently, chromosomal microarray is useful for detection of copy number variants $(\mathrm{CNV})$ when no disease-causing variants have been detected after exome sequencing or when $\mathrm{CNV}$ prediction data indicated the presence of a relevant CNV [149]. CNV analysis has been performed in CVID to determine the genetic basis of this heterogeneous immunological disorder [150,151].

The gold standard of mutation screening is DNA sequencing using the dideoxy chain termination method, which is considered the first generation of sequencing. This method is highly accurate and can detect point mutations, as well as some deletions and duplications. Sanger sequencing is applied in the diagnosis of circumstances where a single gene or a small set of genes is most likely causative. Sanger sequencing is necessary for validation of variants detected using high throughput sequencing. It is also a reliable and cost-effective method for evaluating family members of an affected patient for known mutations (segregation analysis) [4].

Next-generation sequencing (NGS) plays a key role in the clinical diagnosis of many genetic diseases. Currently, 3 NGS technologies - targeted sequencing (TGS), whole exome sequencing (WES), and whole genome sequencing (WGS) - are used in molecular diagnosis and research in CVID and its newer entities. The most focused NGS approach is TGS, which sequences customizable sets of genetic targets covering a known group of disease-causing genes. The utility of TGS is inherently limited, because it is restricted to a set list of target genes. However, in situations where we have a list of multiple possible genes, TGP is reasonable. WES is a focused technology that sequences only the protein-coding regions, which contain around $85 \%$ of disease-causing mutations and cover $90 \%$ to $95 \%$ of exomes [152]. As most of the known monogenic causes of CVID-like phenotypes were identified in individual patients, rather than large families [153], it may not be rational to use TGS in patients with complex phenotypes where a novel causative gene is possible. The most comprehensive NGS technique is WGS, which covers the entire span of human DNA, including both coding and noncoding regions. WGS is not widely used clinically in CVID and is the final choice where previous methods such as TGP and WES cannot find a causative variant [154]. Finally, a genetic investigation could help to improve prognosis, guide follow-up, and ensure appropriate genetic counseling. 


\section{Classification}

Given the various clinical and immunological features of CVID, it seems logical to provide a classification. To date, several classifications have been proposed based on clinical manifestations and laboratory data. The Freiburg classification was established in 2002 by Warnatz et al [39] based on switched memory and CD $21^{\text {low }}$ B cells. Later, Piqueras et al [40] suggested the Paris classification based on memory B cell populations only. In 2008 Wehr et al [41] established a comprehensive classification that is now known as EUROclass. A fourth classification based on B-cell subset abnormalities was recently proposed by Driessen et al [155].

\section{Freiburg Classification}

The Freiburg classification distinguishes CVID patients based on the percentage of switched memory and CD2 $1^{\text {low }} B$ cells. Indeed, this classification identifies patients with disturbed germinal center reactions and defective early peripheral B-cell differentiation by analyzing CD21 expression. Patients are categorized into 2 groups based on the expression of $\operatorname{IgM}$, IgD, CD27 (as a marker for memory B cells), and CD21: group I, with severely reduced class-switched memory CD27 IgMIgD-B cells (switched memory B cells $<0.4 \%$ ); and group II, with normal switched memory B cells $>0.4 \%$. Group I patients are further subdivided into group Ia, with highly expanded CD21 ${ }^{\text {low }} \mathrm{B}$ cells (CD21 $1^{\text {low }} \mathrm{B}$ cells $>20 \%$ ), and group $\mathrm{Ib}$, with percentages of CD21 1ow B cells $<20 \%$. Splenomegaly and/ or autoimmune manifestations are characteristic features of group Ia $[8,36,40]$.

\section{Paris Classification}

The Paris classification is based on percentages of switched memory B cells and total $\mathrm{CD} 27^{+} \mathrm{B}$ cells. Patients with a reduced percentage of $\mathrm{CD} 27^{+} \mathrm{B}$ cells $<11 \%$ comprise group MB0, while patients with decreased class-switched memory $\mathrm{B}$ cells $<8 \%$ and increased total $\mathrm{CD} 27^{+} \mathrm{B}$ cells $>11 \%$ are classified as MB1. Group MB2 comprises patients who do not fulfill the MB0 or MB1 criteria. According to this classification, the incidence of splenomegaly, granulomatous disease, and lymphoid proliferation was higher in patients in group MB0 than in MB1, whereas the incidence of autoimmunity was higher in patients categorized as MB0 and MB1 [40].

One major difference between the Paris and the Freiburg classifications is that the Paris classification calculates the class-switched memory B cells as a percentage of total B cells, whilst for the Freiburg classification, memory B cells are calculated as a percentage of all peripheral blood lymphocytes. Both classifications show a correlation between disease severity and the proportion of switched memory B cells [41].

\section{EUROclass Classification}

EUROclass is a multicenter European trial that classifies patients based on their percentage of CD19 B cells. Thus, patients with $\leq 1 \%$ CD19 B cells are designated group $\mathrm{B}^{-}$and those with a higher number of $\mathrm{B}$ cells $(>1 \%)$ are designated group $\mathrm{B}^{+}$. Group $\mathrm{B}^{+}$is then divided into $\mathrm{smB}^{-}$, with $\leq 2 \%$ switched memory $\mathrm{B}$ cells, and $\mathrm{smB}^{+}$, with
$>2 \%$ switched memory $\mathrm{B}$ cells. $\mathrm{smB}^{-}$patients are further divided into group $\mathrm{smB}^{-}$Trhi, with $\geq 9 \%$ transitional $\mathrm{B}$ cells $\left(\mathrm{CD} 21^{\text {int }} \mathrm{CD} 38^{++} \operatorname{IgM}^{++}\right)$, and group $\mathrm{smB}^{-} \mathrm{Tr}^{\text {norm }}$, with $<9 \%$ transitional $\mathrm{B}$ cells. In addition, EUROclass distinguishes patients based on the expansion of CD2 $1^{\text {low }} \mathrm{B}$ cells. Patients with $\geq 10 \% \mathrm{CD} 21^{\text {low }} \mathrm{B}$ cells are known as group $\mathrm{CD} 21^{\text {low }}$, and those with $<10 \%$ are categorized as $\mathrm{CD} 21^{\text {norm }}$, thus allowing an overlap between patients with the expansion of CD2 $11^{\text {low }}$ and transitional B cells. This classification is currently the most suitable for predicting complications such as granulomatous disease, lymphadenopathy, and splenomegaly in CVID patients. Based on this classification, severe decreased switched memory B cells are associated with a higher risk for splenomegaly and granulomatous disease. Moreover, splenomegaly is associated with an expansion of CD2 $1^{\text {low }} \mathrm{B}$ cells, while lymphadenopathy is significantly associated with transitional B-cell expansion [41]. In a recent study, we also confirmed an association between the presence of $\mathrm{smB}^{+} \mathrm{CD} 21^{\text {low }}$ and splenomegaly in CVID patients [8].

\section{B-Cell Pattern Classification}

According to this classification, patients are divided into 5 distinct groups based on their B-cell subsets. Patients in group 1, show decreased numbers of transitional B cells along with a reduction in memory B cells. Group 2 patients have a reduced number of transitional B cells, as well as naive, marginal zone-like, and memory B cells. Patients with reduced marginal zone-like and memory B cells are classified in group 3, whilst in group 4, patients show only decreased memory B cells. Finally, patients in group 5 show normal marginal zone-like and memory B cells in combination with a reduced plasmablast count.

\section{Other Immunologic Classifications}

Physiological expression of light chains is slightly excessive, resulting in free light chains detectable in serum (sFLC). Detection of sFLCs in CVID by Hanitsch et al [157] showed that $37 \%$ had normal kappa and lambda chains $\left(\kappa^{+} / \lambda^{+}\right)$, $12 \%$ had reduced kappa chains $\left(\kappa^{-} / \lambda^{+}\right), 5 \%$ had reduced lambda chains $\left(\kappa^{+} / \lambda^{-}\right)$, and $46 \%$ had reductions in both chains $\left(\kappa^{-}\right)$ $\left.\lambda^{-}\right)$. Of note, the authors found a clinical correlation between the $\kappa^{-} / \lambda^{-}$sFLCs phenotype and the development of recurrent pneumonia, bronchiectasis, and lymphoproliferative disease.

In 2008, Chapel et al [103] proposed a classification based on clinical manifestations. According to this classification, patients are divided into 5 distinct clinical phenotypes including no complications, autoimmunity, polyclonal lymphocytic infiltration, enteropathy, and lymphoid malignancy.

\section{Management}

As mentioned above, hypogammaglobulinemia is the hallmark of CVID, and immunoglobulin replacement therapy is the most important therapeutic intervention [156]. Indeed, immunoglobulin replacement therapy decreases the frequency of recurrent and severe infections and consequent hospitalizations [156]. Some patients with comorbidities, patients with protein-losing conditions, and pregnant 
patients, may require dose adjustment $[157,158]$. In addition, prophylactic and therapeutic antibiotics and complementary vaccinations with inactive antigens are recommended in these patients [156]. Vaccination in a subgroup of CVID patients with a postgerminal center B-cell pattern is effective in boosting both humoral and cellular immunity [159]. As hepatic and renal dysfunction is not uncommon in CVID patients, therapeutic modalities should be adjusted when necessary [160].

Furthermore, since CVID patients are prone to noninfectious complications such as autoimmunity, the attending physician should continuously monitor the occurrence of these manifestations. In addition, specific treatment of autoimmune complications with immune modulation might be indicated. Of note, the attending physician may consider immunosuppressive drugs such as abatacept, infliximab, and rituximab in the treatment of autoimmune manifestations of CVID in patients with CTLA-4 and LRBA mutations. mTOR inhibitors can also be considered, especially in patients with PI3K signaling defect [161].

HSCT is a potentially curative approach that has been applied in some cases of CVID, with mixed results. Currently, HSCT is only advised in extremely severe cases of CVID, mostly those associated with cellular immune defects and therapy-resistant autoimmunity because of high mortality despite being beneficial in most survivors. However, it may become a potential treatment for specific genetically characterized forms of CVID [10]

\section{Conclusion}

We reviewed the epidemiology, clinical manifestations, pathogenesis, diagnosis, classification, and management of CVID patients. Our review provides a comprehensive overview of CVID, although it is noteworthy that many highly relevant questions remain unanswered, probably owing to the extreme heterogeneity of this disorder. The establishment of generally accepted diagnostic criteria and the introduction of patients according to these criteria in international registries are mandatory first steps when designing and performing meaningful studies. Identification of patients with monogenic defects within CVID cohorts has helped to increase our understanding of the pathogenesis of this complex disorder and might enable us to offer targeted treatment strategies beyond immunoglobulin replacement therapy in the future.

\section{Funding}

The authors declare that no funding was received for the present study.

\section{Conflicts of Interest}

The authors declare that they have no conflicts of interest.

\section{References}

1. Aghamohammadi A, Allahverdi A, Abolhassani $H$, Moazzami K, Alizadeh H, Gharagozlou M, et al. Comparison of pulmonary diseases in common variable immunodeficiency and X-linked agammaglobulinaemia. Respirology. 2010;15(2):289-95.

2. Aghamohammadi $A$, Abolhassani $H$, Moazzami K, Parvaneh $\mathrm{N}$, Rezaei N. Correlation between common variable immunodeficiency clinical phenotypes and parental consanguinity in children and adults. J Investig Allergol Clin Immunol. 2010;20(5):372-9.

3. Bonilla FA, Barlan I, Chapel H, Costa-Carvalho BT, CunninghamRundles C, de la Morena MT, et al. International Consensus Document (ICON): Common Variable Immunodeficiency Disorders. J Allergy Clin Immunol Pract. 2016;4(1):38-59.

4. Abolhassani $H$, Aghamohammadi A, Fang M, Rezaei N, Jiang C, Liu X, et al. Clinical implications of systematic phenotyping and exome sequencing in patients with primary antibody deficiency. Genet Med. 2019;21(1):243-251

5. Azizi G, Rezaei N, Kiaee F, Tavakolinia N, Yazdani $R$ Mirshafiey $A$, et al. T-Cell Abnormalities in Common Variable Immunodeficiency. J Investig Allergol Clin Immunol. 2016:26(4):233-43.

6. Sharifi L, Mirshafiey A, Rezaei N, Azizi G, Magaji Hamid K, Amirzargar AA, et al. The role of toll-like receptors in B-cell development and immunopathogenesis of common variable immunodeficiency. Expert Rev Clin Immunol. 2016;12(2):195207.

7. Sharifi L, Tavakolinia N, Kiaee F, Rezaei N, Mohsenzadegan $M$, Azizi $G$, et al. A Review on Defects of Dendritic Cells in Common Variable Immunodeficiency. Endocr Metab Immune Disord Drug Targets. 2017:17(2):100-13.

8. Yazdani R, Seify R, Ganjalikhani-Hakemi M, Abolhassani $H$, Eskandari N, Golsaz-Shirazi F, et al. Comparison of various classifications for patients with common variable immunodeficiency (CVID) using measurement of B-cell subsets. Allergol Immunopathol (Madr). 2017;45(2):183-92.

9. Gathmann B, Mahlaoui N, Ceredih, Gerard L, Oksenhendler E, Warnatz K, et al. Clinical picture and treatment of 2212 patients with common variable immunodeficiency. J Allergy Clin Immunol. 2014;134(1):116-26.

10. Wehr C, Gennery AR, Lindemans C, Schulz A, Hoenig M, Marks $R$, et al. Multicenter experience in hematopoietic stem cell transplantation for serious complications of common variable immunodeficiency. J Allergy Clin Immunol. 2015;135(4):988-97.

11. Cunningham-Rundles C, Maglione PJ. Common variable immunodeficiency. J Allergy Clin Immunol. 2012;129(5):14256.

12. Modell V, Orange JS, Quinn J, Modell F. Global report on primary immunodeficiencies: 2018 update from the Jeffrey Modell Centers Network on disease classification, regional trends, treatment modalities, and physician reported outcomes. Immunol Res. 2018;66(3):367-80.

13. Shillitoe B, Bangs C, Guzman D, Gennery AR, Longhurst HJ, Slatter $M$, et al. The United Kingdom Primary Immune Deficiency (UKPID) registry 2012 to 2017. Clin Exp Immunol. 2018;192(3):284-91.

14. Sanchez LA, Maggadottir SM, Pantell MS, Lugar P, Rundles CC, Sullivan KE, et al. Two Sides of the Same Coin: Pediatric-Onset and Adult-Onset Common Variable Immune Deficiency. J Clin Immunol. 2017:37(6):592-602

15. Yazdani R, Abolhassani H, Kiaee F, Habibi S, Azizi G, Tavakol $\mathrm{M}$, et al. Comparison of Common Monogenic Defects in a 
Large Predominantly Antibody Deficiency Cohort. J Allergy Clin Immunol Pract. 2019;7(3):864-78.

16. Rae W. Indications to Epigenetic Dysfunction in the Pathogenesis of Common Variable Immunodeficiency. Arch Immunol Ther Exp (Warsz). 2017;65(2):101-10.

17. Rodriguez-Cortez VC, Del Pino-Molina L, Rodriguez-Ubreva J, Ciudad L, Gomez-Cabrero D, Company C, et al. Monozygotic twins discordant for common variable immunodeficiency reveal impaired DNA demethylation during naive-to-memory B-cell transition. Nat Commun. 2015;6:7335.

18. Martinez-Gallo M, Radigan L, Almejun MB, Martinez-Pomar $\mathrm{N}$, Matamoros N, Cunningham-Rundles C. TACI mutations and impaired B-cell function in subjects with CVID and healthy heterozygotes. J Allergy Clin Immunol. 2013;131(2):468-76.

19. Kutukculer N, Gulez N, Karaca NE, Aksu G, Berdeli A. Three different classifications, B lymphocyte subpopulations, TNFRSF13B (TACI), TNFRSF13C (BAFF-R), TNFSF13 (APRIL) gene mutations, CTLA-4 and ICOS gene polymorphisms in Turkish patients with common variable immunodeficiency. J Clin Immunol. 2012;32(6):1165-79.

20. Romberg N, Chamberlain N, Saadoun D, Gentile M, Kinnunen $\mathrm{T}$, Ng YS, et al. CVID-associated TACl mutations affect autoreactive $B$ cell selection and activation. J Clin Invest. 2013;123(10):4283-93

21. Bousfiha A, Jeddane L, Picard C, Ailal F, Bobby Gaspar H, Al-Herz W, et al. The 2017 IUIS Phenotypic Classification for Primary Immunodeficiencies. J Clin Immunol. 2018;38(1):129-43.

22. Tallmadge RL, Shen L, Tseng CT, Miller SC, Barry J, Felippe MJ. Bone marrow transcriptome and epigenome profiles of equine common variable immunodeficiency patients unveil block of $B$ lymphocyte differentiation. Clin Immunol. 2015;160(2):26176.

23. Kramer NJ,WangWL, Reyes EY, Kumar B, Chen CC, Ramakrishna $\mathrm{C}$, et al. Altered lymphopoiesis and immunodeficiency in miR142 null mice. Blood. 2015;125(24):3720-30.

24. Heo JB, Lee YS, Sung S. Epigenetic regulation by long noncoding RNAs in plants. Chromosome Res. 2013;21(6-7):685-93.

25. Eden S, Cedar H. Role of DNA methylation in the regulation of transcription. Curr Opin Genet Dev. 1994;4(2):255-9

26. Zhou H, Hu H, Lai M. Non-coding RNAs and their epigenetic regulatory mechanisms. Biol Cell. 2010;102(12):645-55.

27. Rodriguez A, Vigorito E, Clare S, Warren MV, Couttet $P$, Soond $D R$, et al. Requirement of bic/microRNA-155 for normal immune function. Science. 2007;316(5824):608-11.

28. Lindsley AW, Saal HM, Burrow TA, Hopkin RJ, Shchelochkov O, Khandelwal $P$, et al. Defects of B-cell terminal differentiation in patients with type-1 Kabuki syndrome. J Allergy Clin Immunol. 2016;137(1):179-87.e10.

29. Belkaid Y, Hand TW. Role of the microbiota in immunity and inflammation. Cell. 2014;157(1):121-41.

30. Brenchley JM, Price DA, Schacker TW, Asher TE, Silvestri G, Rao $S$, et al. Microbial translocation is a cause of systemic immune activation in chronic HIV infection. Nat med. 2006;12(12):1365-71.

31. Xavier RJ, Podolsky DK. Unravelling the pathogenesis of inflammatory bowel disease. Nature. 2007;448(7152):42734.

32. Jorgensen SF, Troseid $M$, Kummen $M$, Anmarkrud JA, Michelsen AE, Osnes LT, et al. Altered gut microbiota profile in common variable immunodeficiency associates with levels of lipopolysaccharide and markers of systemic immune activation. Mucosal immunol. 2016;9(6):1455-65.

33. Weller S, Faili A, Garcia C, Braun MC, Le Deist FF, de Saint Basile GG, et al. CD40-CD40L independent Ig gene hypermutation suggests a second B cell diversification pathway in humans. Proc Natl Acad Sci U S A. 2001;98(3):1166-70.

34. Carsetti R, Rosado MM, Donnanno S, Guazzi V, Soresina A, Meini $A$, et al. The loss of IgM memory B cells correlates with clinical disease in common variable immunodeficiency. J Allergy Clin Immunol. 2005;115(2):412-7.

35. Ahn S, Cunningham-Rundles C. Role of B cells in common variable immune deficiency. Expert Rev Clin Immunol. 2009;5(5):557-64.

36. Warnatz K, Schlesier M. Flowcytometric phenotyping of common variable immunodeficiency. Cytometry Part B, Clinical cytometry. 2008;74(5):261-71.

37. Ganjalikhani-Hakemi M, Yazdani R, Esmaeili M, Abolhassani H, Rae W, Azizi G, et al. Role of Apoptosis in the Pathogenesis of Common Variable Immunodeficiency (CVID). Endocr Metab Immune Disord Drug Targets. 2017;17(4):332-40.

38. Yazdani R, Fatholahi M, Ganjalikhani-Hakemi M, Abolhassani $H$, Azizi G, Hamid KM, et al. Role of apoptosis in common variable immunodeficiency and selective immunoglobulin $A$ deficiency. Mol immunol. 2016;71:1-9.

39. Warnatz K, Denz A, Drager R, Braun M, Groth C, WolffVorbeck $G$, et al. Severe deficiency of switched memory B cells $(\mathrm{CD} 27(+) \lg M(-) \lg D(-))$ in subgroups of patients with common variable immunodeficiency: a new approach to classify a heterogeneous disease. Blood. 2002;99(5):1544-51.

40. Piqueras B, Lavenu-Bombled C, Galicier L, Bergeron-van der Cruyssen F, Mouthon L, Chevret $S$, et al. Common variable immunodeficiency patient classification based on impaired $B$ cell memory differentiation correlates with clinical aspects. J Clin Immunol. 2003;23(5):385-400.

41. Wehr C, Kivioja T, Schmitt C, Ferry B, Witte T, Eren E, et al. The EUROclass trial: defining subgroups in common variable immunodeficiency. Blood. 2008;111(1):77-85.

42. Cuss AK, Avery DT, Cannons JL, Yu LJ, Nichols KE, Shaw PJ, et al. Expansion of functionally immature transitional $B$ cells is associated with human-immunodeficient states characterized by impaired humoral immunity. J Immunol. 2006;176(3):150616.

43. Warnatz K, Salzer U, Rizzi M, Fischer B, Gutenberger S, Bohm J, et al. B-cell activating factor receptor deficiency is associated with an adult-onset antibody deficiency syndrome in humans. Proc Natl Acad Sci U S A. 2009;106(33):13945-50.

44. Unger $S$, Seidl $M$, van Schouwenburg $P$, Rakhmanov $M$, Bulashevska A, Frede N, et al. TH1 phenotype of T follicular helper cells indicates an IFNgamma-associated immune dysregulation in CD21low CVID patients. J Allergy Clin Immunol. 2018;141:130-40.

45. Taraldsrud E, Aukrust P, Jorgensen S, Lingjaerde OC, Olweus J, Myklebust JH, et al. Patterns of constitutively phosphorylated kinases in B cells are associated with disease severity in common variable immunodeficiency. Clin immunol. 2017;175:69-74.

46. Giovannetti A, Pierdominici M, Mazzetta F, Marziali $M$, Renzi C, Mileo AM, et al. Unravelling the complexity of $T$ 
cell abnormalities in common variable immunodeficiency. J Immuno. 2007;178(6):3932-43.

47. Vlkova M, Ticha O, Nechvatalova J, Kalina T, Litzman J, Mauri C, et al. Regulatory B cells in CVID patients fail to suppress multifunctional IFN-gamma+ TNF-alpha+ CD4+ T cells differentiation. Clin immunol. 2015;160(2):292-300.

48. Bateman EA, Ayers L, Sadler R, Lucas M, Roberts C, Woods $A$, et al. T cell phenotypes in patients with common variable immunodeficiency disorders: associations with clinical phenotypes in comparison with other groups with recurrent infections. Clin Exp Immunol. 2012;170(2):202-11.

49. Oraei M, Aghamohammadi A, Rezaei N, Bidad K, Gheflati $Z$, Amirkhani $A$, et al. Naive CD4+ T cells and recent thymic emigrants in common variable immunodeficiency. J Investig Allergol Clin Immunol. 2012;22(3):160-7.

50. Rezaei N, Haji-Molla-Hoseini M, Aghamohammadi A, Pourfathollah AA, Moghtadaie M, Pourpak Z. Increased serum levels of soluble CD30 in patients with common variable immunodeficiency and its clinical implications. J Clin Immunol. 2008;28(1):78-84.

51. North ME, Ivory K, Funauchi M, Webster $A D$, Lane AC, Farrant J. Intracellular cytokine production by human $\mathrm{CD} 4+$ and CD8+ T cells from normal and immunodeficient donors using directly conjugated anti-cytokine antibodies and three-colour flow cytometry. Clin Exp Immunol. 1996;105(3):517-22.

52. North ME, Webster AD, Farrant J. Primary defect in CD8+ lymphocytes in the antibody deficiency disease (common variable immunodeficiency): abnormalities in intracellular production of interferon-gamma (IFN-gamma) in CD28+ ('cytotoxic') and CD28- ('suppressor') CD8+ subsets. Clin Exp Immunol. 1998;111(1):70-5.

53. Barbosa RR, Silva SP, Silva SL, Melo AC, Pedro E, Barbosa $M P$, et al. Primary B-cell deficiencies reveal a link between human IL-17-producing CD4 T-cell homeostasis and B-cell differentiation. PloS one. 2011;6(8):e22848.

54. Ganjalikhani-Hakemi M, Yazdani R, Sherkat R, Homayouni $V$, Masjedi M, Hosseini M. Evaluation of the $T$ helper 17 cell specific genes and the innate lymphoid cells counts in the peripheral blood of patients with the common variable immunodeficiency. J Res Med Sci. 2014;19(Suppl 1):S30-5.

55. Coraglia A, Galassi N, Fernandez Romero DS, Juri MC, Felippo M, Malbran A, et al. Common Variable Immunodeficiency and Circulating TFH. J Immunol Res. 2016;2016:4951587.

56. Cunill V, Clemente A, Lanio N, Barcelo C, Andreu V, Pons J, et al. Follicular T Cells from smB(-) Common Variable Immunodeficiency Patients Are Skewed Toward a Th1 Phenotype. Front Immunol. 2017;8:174.

57. Bauquet AT, Jin H, Paterson AM, Mitsdoerffer $M$, Ho IC, Sharpe $\mathrm{AH}$, et al. The costimulatory molecule ICOS regulates the expression of c-Maf and IL-21 in the development of follicular T helper cells and TH-17 cells. Nat Immunol. 2009;10(2):16775.

58. Bossaller L, Burger J, Draeger R, Grimbacher B, Knoth $R$, Plebani $A$, et al. ICOS deficiency is associated with a severe reduction of CXCR5+CD4 germinal center Th cells. J Immunol. 2006;177(7):4927-32.

59. Pellerin L, Jenks JA, Begin P, Bacchetta $R$, Nadeau KC. Regulatory $T$ cells and their roles in immune dysregulation and allergy. Immunol Res. 2014;58(2-3):358-68.
60. Kutukculer N, Azarsiz E, Aksu G, Karaca NE. CD4+CD25+Foxp3+ T regulatory cells, Th1 (CCR5, IL-2, IFN-gamma) and Th2 (CCR4, IL-4, II-13) type chemokine receptors and intracellular cytokines in children with common variable immunodeficiency. Int J Immunopathol Pharmacol. 2016;29(2):241-51.

61. Arandi N, Mirshafiey A, Abolhassani H, Jeddi-Tehrani M, Edalat $R$, Sadeghi $B$, et al. Frequency and expression of inhibitory markers of CD4(+) CD25(+) FOXP3(+) regulatory T cells in patients with common variable immunodeficiency. Scand J Immunol. 2013;77(5):405-12.

62. Genre J, Errante PR, Kokron CM, Toledo-Barros M, Camara NO Rizzo LV. Reduced frequency of CD4(+)CD25(HIGH)FOXP3(+) cells and diminished FOXP3 expression in patients with Common Variable Immunodeficiency: a link to autoimmunity? Clin immunol. 2009;132(2):215-21.

63. Yu GP, Chiang D, Song SJ, Hoyte EG, Huang J, Vanishsarn C, et al. Regulatory $T$ cell dysfunction in subjects with common variable immunodeficiency complicated by autoimmune disease. Clin immunol. 2009;131(2):240-53.

64. Arumugakani G, Wood PM, Carter CR. Frequency of Treg cells is reduced in CVID patients with autoimmunity and splenomegaly and is associated with expanded CD21lo B lymphocytes. J Clin Immunol. 2010;30(2):292-300.

65. Carbone J, Sarmiento E, Micheloud D, Rodriguez-Molina J, Fernandez-Cruz E. Elevated levels of activated CD4 T cells in common variable immunodeficiency: association with clinical findings. Allergol Immunopathol. 2006;34(4):131-5.

66. Viallard JF, Ruiz C, Guillet M, Pellegrin JL, Moreau JF. Perturbations of the CD8(+) T-cell repertoire in CVID patients with complications. Results Immunol. 2013;3:122-8.

67. Carter CR, Aravind G, Smalle NL, Cole JY, Savic S, Wood PM. CVID patients with autoimmunity have elevated T cell expression of granzyme $B$ and HLA-DR and reduced levels of Treg cells. J Clin Pathol. 2013;66(2):146-50.

68. Viallard JF, Blanco $P$, Andre M, Etienne G, Liferman F, Neau D, et al. CD8+HLA-DR+ T lymphocytes are increased in common variable immunodeficiency patients with impaired memory B-cell differentiation. Clin Immunol. 2006;119(1):51-8.

69. Nechvatalova J, Pavlik T, Litzman J, Vlkova M. Terminally differentiated memory $T$ cells are increased in patients with common variable immunodeficiency and selective IgA deficiency. Cent Eur J Immunol. 2017;42(3):244-51.

70. Paquin-Proulx D, Barsotti NS, Santos BA, Marinho AK, Kokron CM, Carvalho KI, et al. Inversion of the Vdelta1 to Vdelta2 gammadelta T cell ratio in CVID is not restored by IVIg and is associated with immune activation and exhaustion. Medicine. 2016;95(30):e4304.

71. Bayry J, Lacroix-Desmazes S, Kazatchkine MD, Galicier $L$, Lepelletier Y, Webster D, et al. Common variable immunodeficiency is associated with defective functions of dendritic cells. Blood. 2004;104(8):2441-3.

72. Cunningham-Rundles C, Radigan L. Deficient IL-12 and dendritic cell function in common variable immune deficiency. Clin Immunol. 2005;115(2):147-53.

73. Cunningham-Rundles C, Radigan L, Knight AK, Zhang L, Bauer $L$, Nakazawa A. TLR9 activation is defective in common variable immune deficiency. J Immunol. 2006;176(3):197887. 
74. Taraldsrud E, Fevang B, Aukrust P, Beiske KH, Floisand $Y$, Froland $S$, et al. Common variable immunodeficiency revisited: normal generation of naturally occurring dendritic cells that respond to Toll-like receptors 7 and 9. Clin Exp Immunol. 2014;175(3):439-48.

75. Aukrust $P$, Muller F, Froland SS. Enhanced generation of reactive oxygen species in monocytes from patients with common variable immunodeficiency. Clin Exp Immunol. 1994;97(2):232-8.

76. Aukrust $P$, Lien E, Kristoffersen AK, Muller F, Haug CJ, Espevik $\mathrm{T}$, et al. Persistent activation of the tumor necrosis factor system in a subgroup of patients with common variable immunodeficiency--possible immunologic and clinical consequences. Blood. 1996;87(2):674-81.

77. Cambronero R, Sewell WA, North ME, Webster AD, Farrant J. Up-regulation of IL-12 in monocytes: a fundamental defect in common variable immunodeficiency. J Immunol. 2000;164(1):488-94.

78. Scott-Taylor TH, Whiting $K$, Pettengell $R$, Webster DA. Enhanced formation of giant cells in common variable immunodeficiency: Relation to granulomatous disease. Clin Immunol. 2017;175:1-9.

79. Yazdani R, Sharifi M, Shirvan AS, Azizi G, Ganjalikhani-Hakemi M. Characteristics of innate lymphoid cells (ILCS) and their role in immunological disorders (an update). Cell Immunol. 2015;298(1-2):66-76.

80. Cols M, Rahman A, Maglione PJ, Garcia-Carmona Y, Simchoni $\mathrm{N}$, Ko HB, et al. Expansion of inflammatory innate lymphoid cells in patients with common variable immune deficiency. J Allergy Clin Immunol. 2016;137(4):1206-15.e1-6.

81. Aspalter RM, Sewell WA, Dolman K, Farrant J, Webster AD. Deficiency in circulating natural killer (NK) cell subsets in common variable immunodeficiency and $X$-linked agammaglobulinaemia. Clin Exp Immunol. 2000;121(3):506-14.

82. Ebbo M, Gérard L, Carpentier S, Vély F, Cypowyj S, Farnarier C, et al. Low Circulating Natural Killer Cell Counts are Associated With Severe Disease in Patients With Common Variable Immunodeficiency. EBioMedicine. 2016;6:222-30.

83. Kutukculer N, Azarsiz E, Karaca NE, Ulusoy E, Koturoglu G, Aksu G. A Clinical and Laboratory Approach to the Evaluation of Innate Immunity in Pediatric CVID Patients. Front Immunol. 2015;6:145.

84. Geier CB, Kraupp S, Bra D, Eibl MM, Farmer JR, Csomos K, et al. Reduced numbers of circulating group 2 innate lymphoid cells in patients with common variable immunodeficiency. Eur J Immunol. 2017;47(11):1959-69.

85. Carvalho KI, Melo KM, Bruno FR, Snyder-Cappione JE, Nixon DF, Costa-Carvalho BT, et al. Skewed distribution of circulating activated natural killer T (NKT) cells in patients with common variable immunodeficiency disorders (CVID). Plos one. 2010;5(9).

86. Erazo-Borras LV, Alvarez-Alvarez JA, Perez-Romero CA, Orrego-Arango JC, Franco-Restrepo JL, Trujillo-Vargas CM. Skewed Invariant Natural Killer T (iNKT) Cells, Impaired iNKT:B Cell Help and Decreased SAP Expression in Blood Lymphocytes from Patients with Common Variable Immunodeficiency. Scand J Immunol. 2017;86(3):171-8.

87. Patuzzo G, Barbieri A, Tinazzi E, Veneri D, Argentino G, Moretta $F$, et al. Autoimmunity and infection in common variable immunodeficiency (CVID). Autoimmun Rev. 2016;15(9):87782.

88. Yazdani $R$, Abolhassani $H$, Asgardoon $M$, Shaghaghi $M$, Modaresi M, Azizi G, et al. Infectious and Noninfectious Pulmonary Complications in Patients With Primary Immunodeficiency Disorders. J Investig Allergol Clin Immunol. 2017;27(4):213-24.

89. Quinti I, Soresina A, Guerra A, Rondelli R, Spadaro G, Agostini $C$, et al. Effectiveness of immunoglobulin replacement therapy on clinical outcome in patients with primary antibody deficiencies: results from a multicenter prospective cohort study. J Clin Immunol. 2011;31(3):315-22.

90. Hampson FA, ChandraA, Screaton NJ, CondliffeA, Kumararatne $D S$, Exley $A R$, et al. Respiratory disease in common variable immunodeficiency and other primary immunodeficiency disorders. Clin Radiol. 2012;67(6):587-95.

91. Kainulainen L, Vuorinen T, Rantakokko-Jalava K, Osterback R, Ruuskanen 0 . Recurrent and persistent respiratory tract viral infections in patients with primary hypogammaglobulinemia. J Allergy Clin Immunol. 2010;126(1):120-6.

92. Pasteur MC, Bilton D, Hill AT, British Thoracic Society Bronchiectasis non CFGG. British Thoracic Society guideline for non-CF bronchiectasis. Thorax. 2010;65 Suppl 1:i1-58.

93. Verma N, Grimbacher B, Hurst JR. Lung disease in primary antibody deficiency. Lancet Respir Med. 2015;3(8):651-60.

94. Oksenhendler E, Gerard L, Fieschi C, Malphettes M, Mouillot G, Jaussaud $R$, et al. Infections in 252 patients with common variable immunodeficiency. Clin Infect Dis. 2008;46(10):1547-54.

95. Malamut G, Verkarre V, Suarez F, Viallard JF, Lascaux AS, Cosnes J, et al. The enteropathy associated with common variable immunodeficiency: the delineated frontiers with celiac disease. Am J Gastroenterol. 2010;105(10):2262-75.

96. Daniels JA, Lederman HM, Maitra A, Montgomery EA. Gastrointestinal tract pathology in patients with common variable immunodeficiency (CVID): a clinicopathologic study and review. Am J Surg Pathol. 2007;31(12):1800-12.

97. Maarschalk-Ellerbroek LJ, Oldenburg B, Mombers IM, Hoepelman Al, Brosens LA, Offerhaus GJ, et al. Outcome of screening endoscopy in common variable immunodeficiency disorder and $\mathrm{X}$-linked agammaglobulinemia. Endoscopy. 2013;45(4):320-3.

98. Everhart JE, Kruszon-Moran D, Perez-Perez GI, Tralka TS, McQuillan G. Seroprevalence and ethnic differences in Helicobacter pylori infection among adults in the United States. J Infect Dis. 2000;181(4):1359-63.

99. Desar IM, van Deuren $M$, Sprong $T$, Jansen JB, Namavar F, Vandenbroucke-Grauls CM, et al. Serum bactericidal activity against Helicobacter pylori in patients with hypogammaglobulinaemia. Clin Exp Immunol. 2009; 156(3):434-9.

100. Chapel H, Cunningham-Rundles C. Update in understanding common variable immunodeficiency disorders (CVIDs) and the management of patients with these conditions. Br J Haematol. 2009;145(6):709-27.

101. Desjardins $M$, Beland $M$, Dembele $M$, Lejtenyi $D$, Drolet $J P$, Lemire $M$, et al. Modulation of the Interleukin-21 Pathway with Interleukin-4 Distinguishes Common Variable Immunodeficiency Patients with More Non-infectious Clinical Complications. J Clin Immunol. 2018;38(1):45-55. 
102. Sarmiento $E$, Mora $R$, Rodriguez-Mahou $M$, RodriguezMolina J, Fernandez-Cruz E, Carbone J. [Autoimmune disease in primary antibody deficiencies]. Allergol Immunopathol. 2005;33(2):69-73.

103. Chapel $H$, Lucas $M$, Lee $M$, Bjorkander J, Webster $D$, Grimbacher B, et al. Common variable immunodeficiency disorders: division into distinct clinical phenotypes. Blood. 2008;112(2):277-86.

104. Ramirez-Vargas N, Arablin-Oropeza SE, Mojica-Martinez D, Yamazaki-Nakashimada MA, de la Luz Garcia-Cruz M, Teran-Juarez LM, et al. Clinical and immunological features of common variable immunodeficiency in Mexican patients. Allergol Immunopathol. 2014;42(3):235-40.

105. Azizi G, Ahmadi M, Abolhassani H, Yazdani R, Mohammadi $H$, Mirshafiey $A$, et al. Autoimmunity in Primary Antibody Deficiencies. Int Arch Allergy Immunol. 2016;171(3-4):180-93.

106. Boileau J, Mouillot G, Gerard L, Carmagnat M, Rabian C, Oksenhendler $E$, et al. Autoimmunity in common variable immunodeficiency: correlation with lymphocyte phenotype in the French DEFI study. J Autoimmun. 2011;36(1):25-32.

107. Resnick ES, Moshier EL, Godbold JH, Cunningham-Rundles C. Morbidity and mortality in common variable immune deficiency over 4 decades. Blood. 2012;119(7):1650-7.

108. Todoric K, Koontz JB, Mattox D, Tarrant TK. Autoimmunity in immunodeficiency. Curr Allergy Asthma Rep. 2013;13(4):36170.

109. Brandt D, Gershwin ME. Common variable immune deficiency and autoimmunity. Autoimmun Rev. 2006;5(7):465-70.

110. Knight AK, Cunningham-Rundles C. Inflammatory and autoimmune complications of common variable immune deficiency. Autoimmun Rev. 2006;5(2):156-9.

111. Xiao X, Miao Q, Chang C, Gershwin ME, Ma X. Common variable immunodeficiency and autoimmunity--an inconvenient truth. Autoimmun Rev. 2014;13(8):858-64.

112. Karaca NE, Aksu G, Yildiz B, Gulez N, Turk B, Dereli T, et al. Relapsing polychondritis in a child with common variable immunodeficiency. Int J Dermatol. 2009;48(5):525-8.

113. Kofod-Olsen E, Jorgensen SE, Nissen SK, Westh L, Moller BK, Ostergaard $L$, et al. Altered fraction of regulatory $B$ and T cells is correlated with autoimmune phenomena and splenomegaly in patients with CVID. Clin Immunol. 2016;162:49-57.

114. Mahmoudi M, Hedayat M, Aghamohammadi A, Rezaei N. Soluble CD26 and CD30 levels in patients with common variable immunodeficiency. J Investig Allergol Clin Immunol. 2013;23(2):120-4.

115. Salek Farrokhi A, Aghamohammadi A, Pourhamdi S, Mohammadinejad P, Abolhassani H, Moazzeni SM. Evaluation of class switch recombination in B lymphocytes of patients with common variable immunodeficiency. J Immunol Methods. 2013;394(1-2):94-9.

116. Warnatz K, Voll RE. Pathogenesis of autoimmunity in common variable immunodeficiency. Front Immunology. 2012;3:210.

117. Baldovino S, Montin D, Martino S, Sciascia S, Menegatti E, Roccatello D. Common variable immunodeficiency: crossroads between infections, inflammation and autoimmunity. Autoimmun Rev. 2013;12(8):796-801.

118. Salavoura K, Kolialexi A, Tsangaris G, Mavrou A. Development of cancer in patients with primary immunodeficiencies. Anticancer Res. 2008;28(2B):1263-9.
119. Mellemkjaer L, Hammarstrom L, Andersen V, Yuen J, Heilmann C, Barington T, et al. Cancer risk among patients with $\lg A$ deficiency or common variable immunodeficiency and their relatives: a combined Danish and Swedish study. Clin Exp Immunol. 2002;130(3):495-500.

120. Dhalla F, da Silva SP, Lucas M, Travis S, Chapel H. Review of gastric cancer risk factors in patients with common variable immunodeficiency disorders, resulting in a proposal for a surveillance programme. Clin Exp Immunol. 2011;165(1):1-7.

121. Uzzan M, Ko HM, Mehandru S, Cunningham-Rundles C. Gastrointestinal Disorders Associated with Common Variable Immune Deficiency (CVID) and Chronic Granulomatous Disease (CGD). Curr Gastroenterol Rep. 2016;18(4):17.

122. Mohebbi A, Azizi G, Tavakolinia N, Abbasi F, Sayarifard F, Karimipour $M$, et al. Comparison of Bone Mineral Density in Common Variable Immunodeficiency and X-Linked Agammaglobulinaemia Patients. Endocr Metab Immune Disord Drug Targets. 2017;17(2):134-40.

123. Ruffner MA, Group UBW, Sullivan KE. Complications Associated with Underweight Primary Immunodeficiency Patients: Prevalence and Associations Within the USIDNET Registry. J Clin Immunol. 2018;38(3):283-93.

124. Yazdani R, Heydari A, Azizi G, Abolhassani H, Aghamohammadi A. Asthma and Allergic Diseases in a Selected Group of Patients With Common Variable Immunodeficiency. J Investig Allergol Clin Immunol. 2016;26(3):209-11.

125. Urm SH, Yun HD, Fenta YA, Yoo KH, Abraham RS, Hagan J, et al. Asthma and risk of selective IgA deficiency or common variable immunodeficiency: a population-based case-control study. Mayo Clin Proc. 2013;88(8):813-21.

126. Agondi RC, Barros MT, Rizzo LV, Kalil J, Giavina-Bianchi P. Allergic asthma in patients with common variable immunodeficiency. Allergy. 2010;65(4):510-5.

127. Nguyen JT, Green A, Wilson MR, DeRisi JL, Gundling K. Neurologic Complications of Common Variable Immunodeficiency. J Clin Immunol. 2016;36(8):793-800.

128. Kurmann R, Weisstanner $C$, Kardas P, Hirsch HH, Wiest R, Lammle $B$, et al. Progressive multifocal leukoencephalopathy in common variable immunodeficiency: mitigated course under mirtazapine and mefloquine. J Neurovirol. 2015;21(6):694-701.

129. Snyder MD, Storch GA, Clifford DB. Atypical PML leading to a diagnosis of common variable immunodeficiency. Neurology. 2005;64(9):1661.

130. Jabbari E, Marshall CR, Longhurst $H$, Sylvester R. Longitudinally extensive transverse myelitis: a rare association with common variable immunodeficiency. Pract Neurol. 2015;15(1):49-52.

131. Danieli MG, Pettinari L, Marinangeli L, Logullo F. Recurrent myelitis in common variable immunodeficiency successfully managed with high-dose subcutaneous immunoglobulin. BMJ Case Rep. 2012;2012.

132. Megias MC, Matei AM, Gonzalez Albarran O, Perez Lopez G. Partial central diabetes insipidus in patient with common variable immunodeficiency. BMJ Case Rep. 2012;2012.

133. Tovo PA, Lala R, Martino S, Pastorelli G, De Sanctis C. Isolated adrenocorticotropic hormone deficiency associated with common variable immunodeficiency. Eur J Pediatr. 1991;150(6):400-2.

134. Aslam A, Misbah SA, Talbot K, Chapel H. Vitamin E deficiency induced neurological disease in common variable 
immunodeficiency: two cases and a review of the literature of vitamin E deficiency. Clin Immunol. 2004;112(1):24-9.

135. Yousry TA, Strupp M, Bruning R. Common variable immunodeficiency leading to spinal subacute combined degeneration monitored by MRI. J Neurol Neurosurg Psychiatry. 1998;64(5):663-6.

136. Ward C, Lucas M, Piris J, Collier J, Chapel H. Abnormal liver function in common variable immunodeficiency disorders due to nodular regenerative hyperplasia. Clin Exp Immunol. 2008;153(3):331-7.

137. Cunningham-Rundles C, Bodian C. Common variable immunodeficiency: clinical and immunological features of 248 patients. Clin Immunol. 1999;92(1):34-48.

138. Malamut G, Ziol M, Suarez F, Beaugrand M, Viallard JF, Lascaux $A S$, et al. Nodular regenerative hyperplasia: the main liver disease in patients with primary hypogammaglobulinemia and hepatic abnormalities. J Hepatol. 2008;48(1):74-82.

139. Ameratunga R, Brewerton M, Slade C, Jordan A, Gillis D, Steele $\mathrm{R}$, et al. Comparison of diagnostic criteria for common variable immunodeficiency disorder. Front Immunol. 2014;5:415.

140. Conley ME, Notarangelo LD, Etzioni A. Diagnostic criteria for primary immunodeficiencies. Representing PAGID (Pan-American Group for Immunodeficiency) and ESID (European Society for Immunodeficiencies). Clin Immunol. 1999:93(3):190-7.

141. de Vries E, Driessen G. Educational paper: Primary immunodeficiencies in children: a diagnostic challenge. Eur J Pediatr. 2011;170(2):169-77.

142. Abolhassani H, Rezaei N, Mohammadinejad P, Mirminachi B, Hammarstrom L, Aghamohammadi A. Important differences in the diagnostic spectrum of primary immunodeficiency in adults versus children. Expert Rev Clin Immunol. 2015;11(2):289302.

143. Azizi G, Abolhassani H, Habibi S, Rahamooz T, Mohammadi $H$, Jafarnezhad-Ansariha $F$, et al. Two Faces of LRBA Deficiency in Siblings: Hypogammaglobulinemia and Normal Immunoglobulin Levels. J Investig Allergol Clin Immunol. 2018;28(1):48-50.

144. Lindegren ML, Kobrynski L, Rasmussen SA, Moore CA, Grosse $\mathrm{SD}$, Vanderford ML, et al. Applying public health strategies to primary immunodeficiency diseases: a potential approach to genetic disorders. MMWR Recomm Rep. 2004;53(Rr-1):1-29.

145. Reust CE. Evaluation of primary immunodeficiency disease in children. Am Fam Physician. 2013;87(11):773-8.

146. Tarzi MD, Grigoriadou S, Carr SB, Kuitert LM, Longhurst HJ. Clinical immunology review series: An approach to the management of pulmonary disease in primary antibody deficiency. Clin Exp Immunol. 2009;155(2):147-55.

147. Clutterbuck EA, Oh S, Hamaluba M, Westcar S, Beverley PC, Pollard AJ. Serotype-specific and age-dependent generation of pneumococcal polysaccharide-specific memory B-cell and antibody responses to immunization with a pneumococcal conjugate vaccine. Clin Vaccine Immunol. 2008;15(2):182-93.

148. Koch A, Melbye M, Sorensen P, Homoe P, Madsen HO, Molbak $K$, et al. Acute respiratory tract infections and mannosebinding lectin insufficiency during early childhood. Jama. 2001;285(10):1316-21.

149. Stray-Pedersen A, Sorte HS, Samarakoon P, Gambin T, Chinn IK, Coban Akdemir ZH, et al. Primary immunodeficiency diseases:
Genomic approaches delineate heterogeneous Mendelian disorders. J Allergy Clin Immunol. 2017;139(1):232-45.

150. Keller M, Glessner J, Resnick E, Perez E, Chapel H, Lucas M, et al. Burden of copy number variation in common variable immunodeficiency. Clin Exp Immunol. 2014;177(1):269-71.

151. Orange JS, Glessner JT, Resnick E, Sullivan KE, Lucas M, Ferry $B$, et al. Genome-wide association identifies diverse causes of common variable immunodeficiency. J Allergy Clin Immunol. 2011;127(6):1360-7.e6.

152. Rehm HL, Bale SJ, Bayrak-Toydemir P, Berg JS, Brown KK, Deignan JL, et al. ACMG clinical laboratory standards for nextgeneration sequencing. Genet Med. 2013;15(9):733-47.

153. Casanova JL, Conley ME, Seligman SJ, Abel L, Notarangelo LD. Guidelines for genetic studies in single patients: lessons from primary immunodeficiencies. J Exp Med. 2014;211(11):213749.

154. Mousallem T, Urban TJ, McSweeney KM, Kleinstein SE, Zhu $M$, Adeli $M$, et al. Clinical application of whole-genome sequencing in patients with primary immunodeficiency. J Allergy Clin Immunol. 2015;136(2):476-9.e6.

155. Driessen GJ, van Zelm MC, van Hagen PM, Hartwig NG, Trip M, Warris A, et al. B-cell replication history and somatic hypermutation status identify distinct pathophysiologic backgrounds in common variable immunodeficiency. Blood. 2011:118(26):6814-23.

156. Salehzadeh M, Aghamohammadi A, Rezaei N. Evaluation of immunoglobulin levels and infection rate in patients with common variable immunodeficiency after immunoglobulin replacement therapy. J Microbiol Immunol Infect. 2010;43(1):11-7.

157. Egawa M, Kanegane $H$, Imai $K$, Morio T, Miyasaka N. Intravenous immunoglobulin (IVIG) efficiency in women with common variable immunodeficiency (CVID) decreases significantly during pregnancy. J Matern Fetal Neonatal Med. 2019;32(18):3092-6.

158. Abolhassani H, Sagvand BT, Shokuhfar T, Mirminachi B, Rezaei $\mathrm{N}$, Aghamohammadi A. A review on guidelines for management and treatment of common variable immunodeficiency. Expert Rev Clin Immunol. 2013;9(6):561-74; quiz 75.

159. Gardulf A, Abolhassani $H$, Gustafson R, Eriksson LE, Hammarstrom L. Predictive markers for humoral influenza vaccine response in patients with common variable immunodeficiency. J Allergy Clin Immunol. 2018.

160. Capistrano GG, Meneses GC, de Oliveira Neves FM, de Almeida Leitao R, Martins AMC, Liborio AB. Renal Evaluation in Common Variable Immunodeficiency. J Immunol Res. 2018;2018:5841031.

161. Azizi G, Ziaee V, Tavakol M, Alinia T, Yazdai R, Mohammadi $\mathrm{H}$, et al. Approach to the Management of Autoimmunity in Primary Immunodeficiency. Scand J Immunol. 2017;85(1):1329.

162. Castigli E, Wilson S, Garibyan L, Rachid R, Bonilla F, Schneider L, et al. Reexamining the role of $\mathrm{TACl}$ coding variants in common variable immunodeficiency and selective IgA deficiency. Nat Genet. 2007;39(4):430-1.

163. Wang HY, Ma CA, Zhao Y, Fan X, Zhou Q, Edmonds P, et al. Antibody deficiency associated with an inherited autosomal dominant mutation in TWEAK. Proc Natl Acad Sci U S A. 2013;110(13):5127-32. 
164. van Montfrans JM, Hoepelman Al, Otto $S$, van Gijn $M$, van de Corput $L$, de Weger RA, et al. CD27 deficiency is associated with combined immunodeficiency and persistent symptomatic EBV viremia. J Allergy Clin Immunol. 2012;129(3):787-93.e6.

165. Alkhairy OK, Perez-Becker R, Driessen GJ, Abolhassani H, van Montfrans J, Borte $S$, et al. Novel mutations in TNFRSF7/CD27: Clinical, immunologic, and genetic characterization of human CD27 deficiency. J Allergy Clin Immunol. 2015;136(3):70312.e10.

166. Kanegane H, Agematsu K, Futatani T, Sira MM, Suga K, Sekiguchi $T$, et al. Novel mutations in a Japanese patient with CD19 deficiency. Genes Immun. 2007;8(8):663-70.

167. van Zelm MC, Reisli I, van der Burg M, Castano D, van Noesel CJ, van Tol MJ, et al. An antibody-deficiency syndrome due to mutations in the CD19 gene. N Engl J Med. 2006;354(18):1901-12.

168. van Zelm MC, Smet J, Adams B, Mascart F, Schandene L, Janssen $F$, et al. CD81 gene defect in humans disrupts CD19 complex formation and leads to antibody deficiency. J Clin Invest. 2010;120(4):1265-74.

169. Vences-Catalan F, Kuo CC, Sagi Y, Chen H, Kela-Madar N, van Zelm MC, et al. A mutation in the human tetraspanin CD81 gene is expressed as a truncated protein but does not enable CD19 maturation and cell surface expression. J Clin Immunol. 2015;35(3):254-63.

170. van Zelm MC, Bartol SJ, Driessen GJ, Mascart F, Reisli I, Franco $J$, et al. Human CD19 and CD40L deficiencies impair antibody selection and differentially affect somatic hypermutation. J Allergy Clin Immunol. 2014;134(1):135-44.

171. Kotlarz D, Zietara N, Uzel G, Weidemann T, Braun CJ, Diestelhorst J, et al. Loss-of-function mutations in the IL-21 receptor gene cause a primary immunodeficiency syndrome. J Exp Med. 2013;210(3):433-43.

172. Salzer E, Kansu A, Sic H, Majek P, Ikinciogullari A, Dogu FE, et al. Early-onset inflammatory bowel disease and common variable immunodeficiency-like disease caused by IL-21 deficiency. J Allergy Clin Immunol. 2014;133(6):1651-9.e12.

173. Stepensky P, Keller B, Abuzaitoun O, Shaag A, Yaacov B, Unger $S$, et al. Extending the clinical and immunological phenotype of human interleukin-21 receptor deficiency. Haematologica. 2015;100(2):e72-6.

174. Ettinger $R$, Sims GP, Fairhurst AM, Robbins $R$, da Silva $Y S$, Spolski $R$, et al. IL-21 induces differentiation of human naive and memory B cells into antibody-secreting plasma cells. J Immunol. 2005; 175(12):7867-79.

175. Salzer U, Maul-Pavicic A, Cunningham-Rundles C, Urschel S, Belohradsky BH, Litzman J, et al. ICOS deficiency in patients with common variable immunodeficiency. Clin Immunol. 2004;113(3):234-40

176. Kuijpers TW, Bende RJ, Baars PA, Grummels A, Derks IA, Dolman KM, et al. CD20 deficiency in humans results in impaired T cell-independent antibody responses. J Clin Invest. 2010;120(1):214-22

177. van der Heijden J, Geissler J, van Mirre $E$, van Deuren $M$, van der Meer JW, Salama A, et al. A novel splice variant of FcgammaRlla: a risk factor for anaphylaxis in patients with hypogammaglobulinemia. J Allergy Clin Immunol. 2013;131(5):1408-16.e5.
178. Flinsenberg TW, Janssen WJ, Herczenik E, Boross P, Nederend $\mathrm{M}$, Jongeneel $\mathrm{LH}$, et al. A novel FcgammaRlla Q27W gene variant is associated with common variable immune deficiency through defective FcgammaRIla downstream signaling. Clin Immunol. 2014;155(1):108-17.

179. Yu JE, Zhang L, Radigan L, Sanchez-Ramon S, CunninghamRundles C. TLR-mediated B cell defects and IFN-alpha in common variable immunodeficiency. J Clin Immunol. 2012;32(1):50-60.

180. Kuehn HS, Ouyang W, Lo B, Deenick EK, Niemela JE, Avery DT, et al. Immune dysregulation in human subjects with heterozygous germline mutations in CTLA4. Science. 2014;345(6204):1623-7.

181. Belot A, Kasher PR, Trotter EW, Foray AP, Debaud AL, Rice $\mathrm{Gl}$, et al. Protein kinase cdelta deficiency causes mendelian systemic lupus erythematosus with B cell-defective apoptosis and hyperproliferation. Arthritis Rheum. 2013;65(8):2161-71.

182. Kuehn HS, Niemela JE, Rangel-Santos A, Zhang M, Pittaluga $S$, Stoddard $J$, et al. Loss-of-function of the protein kinase $C$ delta (PKCdelta) causes a B-cell lymphoproliferative syndrome in humans. Blood. 2013;121(16):3117-25.

183. Salzer E, Santos-Valente E, Klaver S, Ban SA, Emminger W, Prengemann NK, et al. B-cell deficiency and severe autoimmunity caused by deficiency of protein kinase $C$ delta. Blood. 2013;121(16):3112-6.

184. Gorjestani S, Yu M, Tang B, Zhang D, Wang D, Lin X. Phospholipase Cgamma2 (PLCgamma2) is key component in Dectin-2 signaling pathway, mediating anti-fungal innate immune responses. J Biol Chem. 2011;286(51):43651-9.

185. Ombrello MJ, Remmers EF, Sun G, Freeman AF, Datta $S$, Torabi-Parizi $P$, et al. Cold urticaria, immunodeficiency, and autoimmunity related to PLCG2 deletions. N Engl J Med. 2012;366(4):330-8.

186. Elgizouli M, Lowe DM, Speckmann C, Schubert D, Hulsdunker J, Eskandarian Z, et al. Activating PI3Kdelta mutations in a cohort of 669 patients with primary immunodeficiency. Clin Exp Immunol. 2016;183(2):221-9.

187. Lucas CL, Zhang Y, Venida A, Wang Y, Hughes J, McElwee J, et al. Heterozygous splice mutation in PIK3R 1 causes human immunodeficiency with lymphoproliferation due to dominant activation of PI3K. J Exp Med. 2014;211(13):2537-47.

188. Deau MC, Heurtier L, Frange P, Suarez F, Bole-Feysot C, Nitschke $P$, et al. A human immunodeficiency caused by mutations in the PIK3R1 gene. J Clin Invest. 2014;124(9):3923-8.

189. Compeer $E B$, Janssen $W$, van Royen-Kerkhof $A$, van Gijn $M$, van Montfrans JM, Boes M. Dysfunctional BLK in common variable immunodeficiency perturbs B-cell proliferation and ability to elicit antigen-specific CD4+ T-cell help. Oncotarget. 2015;6(13):10759-71.

190. Fischer MB, Wolf HM, Hauber I, Eggenbauer $H$, Thon V, Sasgary $M$, et al. Activation via the antigen receptor is impaired in $T$ cells, but not in B cells from patients with common variable immunodeficiency. Eur J Immunol. 1996;26(1):231-7.

191. Li PL. Changes of intracellular IP3 with the expression of interleukin 2 receptor in human peripheral blood $T$ lymphocytes. J Tongji Med Univ. 1991;11(2):88-92.

192. Sawabe T, Horiuchi T, Nakamura M, Tsukamoto $H$, Nakahara $\mathrm{K}$, Harashima SI, et al. Defect of Ick in a patient with common variable immunodeficiency. Int J Mol Med. 2001;7(6):609-14. 
193. Capitani N, Amedei A, Paccani SR, Matucci A, Vultaggio A, Del Prete $G$, et al. Impaired $T H 2$ response in patients with Vav1-deficient common variable immunodeficiency with T-cell defects. J Allergy Clin Immunol. 2010;126(3):671-5.

194. Capitani N, Ariani F, Amedei A, Pezzicoli A, Matucci A, Vultaggio $A$, et al. Vav1 haploinsufficiency in a common variable immunodeficiency patient with defective T-cell function. Int J Immunopathol Pharmacol. 2012;25(3):811-7.

195. Kurkchubasche AG, Panepinto JA, Tracy TF, Jr., Thurman GW, Ambruso DR. Clinical features of a human Rac2 mutation: a complex neutrophil dysfunction disease. J Pediatr. 2001;139(1):141-7.

196. Ambruso DR, Knall C, Abell AN, Panepinto J, Kurkchubasche A, Thurman $G$, et al. Human neutrophil immunodeficiency syndrome is associated with an inhibitory Rac2 mutation. Proc Natl Acad Sci U S A. 2000;97(9):4654-9.

197. Alkhairy OK, Rezaei N, Graham RR, Abolhassani H, Borte S, Hultenby K, et al. RAC2 loss-of-function mutation in 2 siblings with characteristics of common variable immunodeficiency. J Allergy Clin Immunol. 2015;135(5):1380-4 e1-5.

198. Boncristiano M, Majolini MB, D'Elios MM, Pacini S, Valensin S,

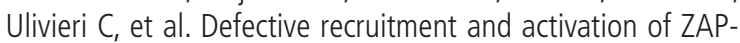
70 in common variable immunodeficiency patients with $T$ cell defects. Eur J mmunol. 2000;30(9):2632-8.

199. Lo B, Zhang K, Lu W, Zheng L, Zhang Q, Kanellopoulou C, et al. AUTOIMMUNE DISEASE. Patients with LRBA deficiency show CTLA4 loss and immune dysregulation responsive to abatacept therapy. Science. 2015;349(6246):436-40.

200. Lopez-Herrera G, Tampella G, Pan-Hammarstrom Q, Herholz P, Trujillo-Vargas CM, Phadwal K, et al. Deleterious mutations in LRBA are associated with a syndrome of immune deficiency and autoimmunity. Am J Hum Genet. 2012;90(6):986-1001.

201. Gamez-Diaz L, August D, Stepensky P, Revel-Vilk S, Seidel MG, Noriko $M$, et al. The extended phenotype of LPS-responsive beige-like anchor protein (LRBA) deficiency. J Allergy Clin Immunol. 2016;137(1):223-30.

202. Visentini M, Marrapodi R, Conti V, Mitrevski M, Camponeschi A, Lazzeri $C$, etal. Dysregulated extracellular signal-regulated kinase signaling associated with impaired B-cell receptor endocytosis in patients with common variable immunodeficiency. J Allergy Clin Immunol. 2014;134(2):401-10.

203. Stepensky P, Keller B, Buchta M, Kienzler AK, Elpeleg O, Somech $\mathrm{R}$, et al. Deficiency of caspase recruitment domain family, member 11 (CARD11), causes profound combined immunodeficiency in human subjects. J Allergy Clin Immunol. 2013;131(2):477-85.e1.

204. Tampella G, Baronio M, Vitali M, Soresina A, Badolato R, Giliani $S$, et al. Evaluation of CARMA1/CARD11 and Bob1 as candidate genes in common variable immunodeficiency. J Investig Allergol Clin Immunol. 2011;21(5):348-53.

205. Lindner JM, Wong CS, Moller A, Nielsen PJ. A C-terminal acidic domain regulates degradation of the transcriptional coactivator Bob1. Mol Cell Biol. 2013;33(23):4628-40.

206. Plebani A, Lougaris V, Soresina A, Meini A, Zunino F, Losi $C G$, et al. A novel immunodeficiency characterized by the exclusive presence of transitional $B$ cells unresponsive to $\mathrm{CpG}$. Immunology. 2007;121(2):183-8.

207. Chen K, Coonrod EM, Kumanovics A, Franks ZF, Durtschi JD, Margraf $\mathrm{RL}$, et al. Germline mutations in NFKB2 implicate the noncanonical NF-kappaB pathway in the pathogenesis of common variable immunodeficiency. Am J Hum Genet. 2013;93(5):812-24.

208. Shi C, Wang F, Tong A, Zhang XQ, Song HM, Liu ZY, et al. NFKB2 mutation in common variable immunodeficiency and isolated adrenocorticotropic hormone deficiency: A case report and review of literature. Medicine. 2016;95(40):e5081.

209. Liu Y, Hanson S, Gurugama P, Jones A, Clark B, Ibrahim MA. Novel NFKB2 mutation in early-onset CVID. J Clin Immunol. 2014;34(6):686-90.

210. Kuehn HS, Boisson B, Cunningham-Rundles C, Reichenbach J, Stray-Pedersen A, Gelfand EW, et al. Loss of B Cells in Patients with Heterozygous Mutations in IKAROS. N Engl J Med. 2016;374(11):1032-43.

211. Kobbe R, Kolster M, Fuchs S, Schulze-Sturm U, Jenderny J, Kochhan L, et al. Common variable immunodeficiency, impaired neurological development and reduced numbers of $\mathrm{T}$ regulatory cells in a 10-year-old boy with a STAT1 gain-offunction mutation. Gene. 2016;586(2):234-8.

212. Keller MD, Pandey R, Li D, Glessner J, Tian L, Henrickson SE, et al. Mutation in IRF2BP2 is responsible for a familial form of common variable immunodeficiency disorder. J Allergy Clin Immunol. 2016;138(2):544-50.e4.

213. Abolhassani $H$, Edwards $E S$, Ikinciogullari $A$, Jing $H$, Borte $S$, Buggert $M$, et al. Combined immunodeficiency and EpsteinBarr virus-induced B cell malignancy in humans with inherited CD70 deficiency. J Exp Med. 2017;214(1):91-106.

214. Schubert D, Klein MC, Hassdenteufel S, Caballero-Oteyza A, Yang L, Proietti M, et al. Plasma cell deficiency in human subjects with heterozygous mutations in Sec61 translocon alpha 1 subunit (SEC61A1). J Allergy Clin Immunol. 2018;141(4):1427-38.

215. Jansen EJ, Timal $S$, Ryan $M$, Ashikov $A$, van Scherpenzeel M, Graham LA, et al. ATP6AP1 deficiency causes an immunodeficiency with hepatopathy, cognitive impairment and abnormal protein glycosylation. Nat Commun. 2016;7:11600.

216. Rider NL, Boisson B, Jyonouchi S, Hanson EP, Rosenzweig SD, Cassanova JL, et al. Novel TTC37 Mutations in a Patient with Immunodeficiency without Diarrhea: Extending the Phenotype of Trichohepatoenteric Syndrome. Front Pediatr. 2015;3:2.

217. Chakraborty PK, Schmitz-Abe K, Kennedy EK, Mamady H, Naas T, Durie $D$, et al. Mutations in TRNT1 cause congenital sideroblastic anemia with immunodeficiency, fevers, and developmental delay (SIFD). Blood. 2014;124(18):2867-71.

218. Tsujita Y, Mitsui-Sekinaka K, Imai K, Yeh TW, Mitsuiki N, Asano $T$, et al. Phosphatase and tensin homolog (PTEN) mutation can cause activated phosphatidylinositol 3-kinase delta syndrome-like immunodeficiency. J Allergy Clin Immunol. 2016;138(6):1672-80.e10.

219. Taubenheim N, von Hornung M, Durandy A, Warnatz $K$, Corcoran L, Peter HH, et al. Defined blocks in terminal plasma cell differentiation of common variable immunodeficiency patients. J immunol. 2005;175(8):5498-503.

220. Rezaei N, Aghamohammadi A, Kardar GA, Nourizadeh M, Pourpak Z. T- helper 1 and 2 cytokine assay in patients with common variable immunodeficiency. J Investig Allergol Clin Immunol. 2008;18(6):449-53. 
221. Katial RK, Lieberman MM, Muehlbauer SL, Lust JA, Hamilos DL. Gamma delta T lymphocytosis associated with common variable immunodeficiency. J Clin Immunol. 1997;17(1):3442.

222. Viallard JF, Bloch-Michel C, Caubet O, Parrens M, TexierMaugein J, Neau-Cransac M, et al. Gammadelta T lymphocytosis associated with granulomatous disease in a patient with common variable immunodeficiency. Clin Infect Dis. 2002;35(12):e134-7.

223. Viallard JF, Camou F, Andre M, Liferman F, Moreau JF, Pellegrin $J \mathrm{~L}$, et al. Altered dendritic cell distribution in patients with common variable immunodeficiency. Arthritis Res Ther. 2005; 7(5):R1052-5

224. Martinez-Pomar N, Raga S, Ferrer J, Pons J, Munoz-Saa I, Julia MR, et al. Elevated serum interleukin (IL)-12p40 levels in common variable immunodeficiency disease and decreased peripheral blood dendritic cells: analysis of IL-12p40 and interferon-gamma gene. Clin Exp Immunol. 2006;144(2):233-8.
225. Cols M, Rahman A, Maglione PJ, Garcia-Carmona Y, Simchoni $\mathrm{N}$, Ko HM, et al. Expansion of inflammatory innate lymphoid cells in patients with common variable immune deficiency. J Allergy Clin Immunol. 2016;137(4):1206-15.e6.

\footnotetext{
Manuscript received October 10, 2018; accepted for publication February 7, 2019.
}

\section{- Asghar Aghamohammadi}

Children's Medical Center Hospital 62 Qarib St., Keshavarz Blvd., Tehran 14194, Iran E-mail: aghamohammadi@sina.tums.ac.ir 